Prepared for the U.S. Department of Energy

under Contract DE-AC05-76RL01830

\title{
Evolution of Safeguards Over Time: Past, Present, and Projected Facilities, Material, and Budget
}

\section{Kollar}

CE Mathews

July 2009

\section{Pacific Northwest}

NATIONAL LABORATORY

Proudly Operated by Battelle Since 1965 


\title{
DISCLAIMER
}

This report was prepared as an account of work sponsored by an agency of the United States Government. Neither the United States Government nor any agency thereof, nor Battelle Memorial Institute, nor any of their employees, makes any warranty, express or implied, or assumes any legal liability or responsibility for the accuracy, completeness, or usefulness of any information, apparatus, product, or process disclosed, or represents that its use would not infringe privately owned rights. Reference herein to any specific commercial product, process, or service by trade name, trademark, manufacturer, or otherwise does not necessarily constitute or imply its endorsement, recommendation, or favoring by the United States Government or any agency thereof, or Battelle Memorial Institute. The views and opinions of authors expressed herein do not necessarily state or reflect those of the United States Government or any agency thereof.

\author{
PACIFIC NORTHWEST NATIONAL LABORATORY \\ operated by \\ BATTELLE \\ for the \\ UNITED STATES DEPARTMENT OF ENERGY \\ under Contract DE-AC05-76RL01830
}

Printed in the United States of America

Available to DOE and DOE contractors from the

Office of Scientific and Technical Information,

P.O. Box 62, Oak Ridge, TN 37831-0062;

ph: (865) 576-8401

fax: $(865)$ 576-5728

email: reports@adonis.osti.gov

\footnotetext{
Available to the public from the National Technical Information Service, U.S. Department of Commerce, 5285 Port Royal Rd., Springfield, VA 22161 ph: (800) 553-6847 fax: $(703) 605-6900$

email: orders@ntis.fedworld.gov

online ordering: http://www.ntis.gov/ordering.htm
}

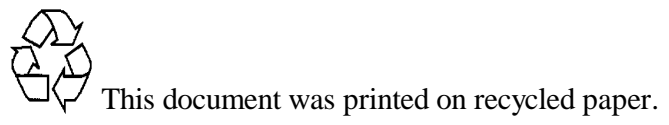




\section{Evolution of Safeguards Over Time: Past, Present, and Projected Facilities, Material, and Budget}

L Kollar

CE Mathews

July 2009

Prepared for the U.S. Department of Energy under Contract DE-AC05-76RL01830

Pacific Northwest National Laboratory

Richland, Washington 99352 


\section{Evolution of Safeguards over Time: Past, Present, and Projected Facilities, Material, and Budget}

Lenka Kollar

Pacific Northwest National Laboratory

July 23, 2009

\section{Introduction}

The International Atomic Energy Agency (IAEA) was formed in 1957 in order to promote safe, secure, and peaceful application of nuclear technologies to the betterment of mankind. One of the main goals of the IAEA is to safeguard nuclear material from diversion into non-peaceful uses and thus prevent nuclear proliferation. There are 187 signatories to the Nuclear Nonproliferation Treaty, and all non-nuclear weapon state parties must conclude a safeguards agreement with the IAEA. As the number of nuclear facilities and volume of nuclear material grows, so does the extent of safeguards. While safeguards activities have grown significantly over the 50 year course of the IAEA, the safeguards budget has not grown at the same rate. Also, a zero real growth safeguards budget scenario is predicted for the future, despite expected increased demand for safeguards activities throughout the world.

This study examines the past trends and evolution of safeguards over time and projects growth through 2030. The report documents the amount of nuclear material and facilities under safeguards from 1970 until present, along with the corresponding budget. Estimates for the future amount of facilities and material under safeguards are made according to non-nuclearweapons states' (NNWS) plans to build more nuclear capacity and sustain current nuclear infrastructure. Since nuclear energy is seen as a clean and economic option for base load electric power, many countries are seeking to either expand their current nuclear infrastructure, or introduce nuclear power. In order to feed new nuclear power plants and sustain existing ones, more nuclear facilities will need to be built, and thus more nuclear material will be introduced into the safeguards system. The projections in this study conclude that a zero real growth scenario for the IAEA safeguards budget will result in large resource gaps in the near future.

\section{Safeguarded Facilities and Nuclear Material 1970 to Present}

In 1970 there were only 82 facilities under IAEA safeguards: 10 nuclear power plants, 68 research reactors and 4 fuel fabrication plants, along with 74 other locations. The most current numbers from 2007 show that there are now 648 nuclear installations: 236 nuclear power plants, 151 research reactors, 18 conversion plants, 42 fuel fabrication plants, 8 reprocessing plants, 15 enrichment plants, 101 separate storage facilities and 77 other facilities, along with an additional 481 other locations. These facilities are listed by state in Appendix A. The breakdown of the number of installations by the type of facility under IAEA safeguards from 1970 to 2007 is shown in Figure 1. The most dramatic increase occurred in the 1970s, followed by a gradual increase until the late 1990s. The 2000s have not seen an increase in the number of safeguarded facilities thus far; however, many countries have plants currently under construction or planned that will consume safeguards resources in the very near future. 


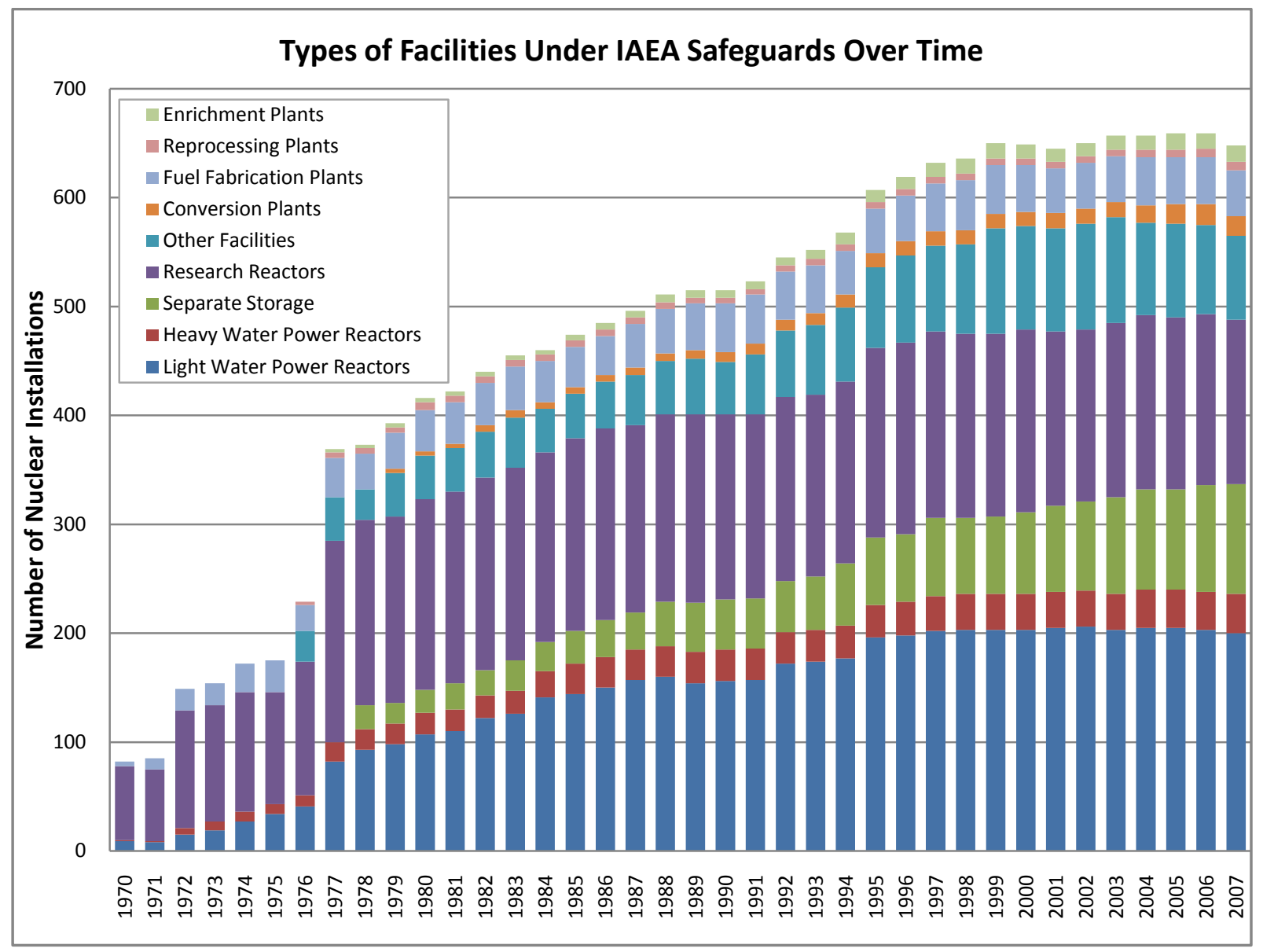

Figure 1: Number of installations under IAEA safeguards by type from 1970 to present. ${ }^{1}$

It is important to note that some facilities consume higher levels of safeguards resources than others. For example, light water power reactors (LWRs) are generally simpler to apply safeguards to than heavy water power reactors (HWRs) because LWRs use large fuel assemblies that are replaced during specific outage periods when the reactor is shutdown, while HWRs use smaller fuel assemblies than can be replaced while the reactor is online, thus making it difficult to achieve safeguards objectives in a timely fashion, and also offer additional diversion paths which must be addressed through the safeguards approach. Conversion and enrichment facilities also consume significant safeguards resources because they process material in bulk form, and enrichment plants present challenges in protecting against all diversion or misuse scenarios. Some LEU fuel fabrication plants and most storage facilities allow item accounting methods to dominate the safeguards approach, which also can facilitate the use of short-notice random inspections. Reprocessing plants separate plutonium and uranium from spent fuel and thus have a high potential for diversion or misuse, and pose challenges related to timeliness and meeting detection objectives due to large throughputs and measurement uncertainties. Research facilities use relatively much smaller amounts of nuclear material than commercial facilities, but still require application of safeguards and careful monitoring of a dynamic design-information environment.

\footnotetext{
${ }^{1}$ Source: IAEA Annual Reports for 1970 to 2007, www.iaea.org/About/Policy/GC/GC51/Agenda/
} 
Correlating to the increase in the number of safeguarded facilities over time, the amount of safeguarded nuclear material has also dramatically increased. To sustain operating nuclear power plants, uranium must be mined, milled, converted, usually enriched, and fabricated into fuel. All of this material entering safeguarded facilities is then also monitored under safeguards, thus constantly increasing the amount of nuclear material under safeguards. Far less material is removed from safeguards (as waste, for example) than is introduced into the fuel cycle. Nuclear material usually enters safeguards at a conversion facility, before entering an enrichment or fuel fabrication plant.

While commercial uranium for nuclear power plants is low enriched (LEU), high enriched uranium (HEU) and plutonium are sometimes used in research reactors and other research facilities around the world. The IAEA has designated the amount of a certain type of nuclear material that would be needed to make a nuclear weapon as a significant quantity (SQ) of material. A significant quantity of LEU is $75 \mathrm{~kg}$, but only $8 \mathrm{~kg}$ for plutonium and $25 \mathrm{~kg}$ for HEU, calculated in the total of the isotope U-235 or element Pu contained. ${ }^{2}$

The significant increase of safeguarded material over time is shown in Figure 2. In 1970 there were 447 SQs of material under IAEA safeguards. There are currently 151,749 safeguarded SQs, a more than 300 fold increase in only 40 years. Since nuclear material will continue to accumulate, there is estimated to be an increasing trend of safeguarded material in the future as current power plants continue to operate and new ones are built.

\footnotetext{
${ }^{2}$ Source: "The Evolution of International Safeguards" presentation by Jim Tape, June 8, 2009
} 


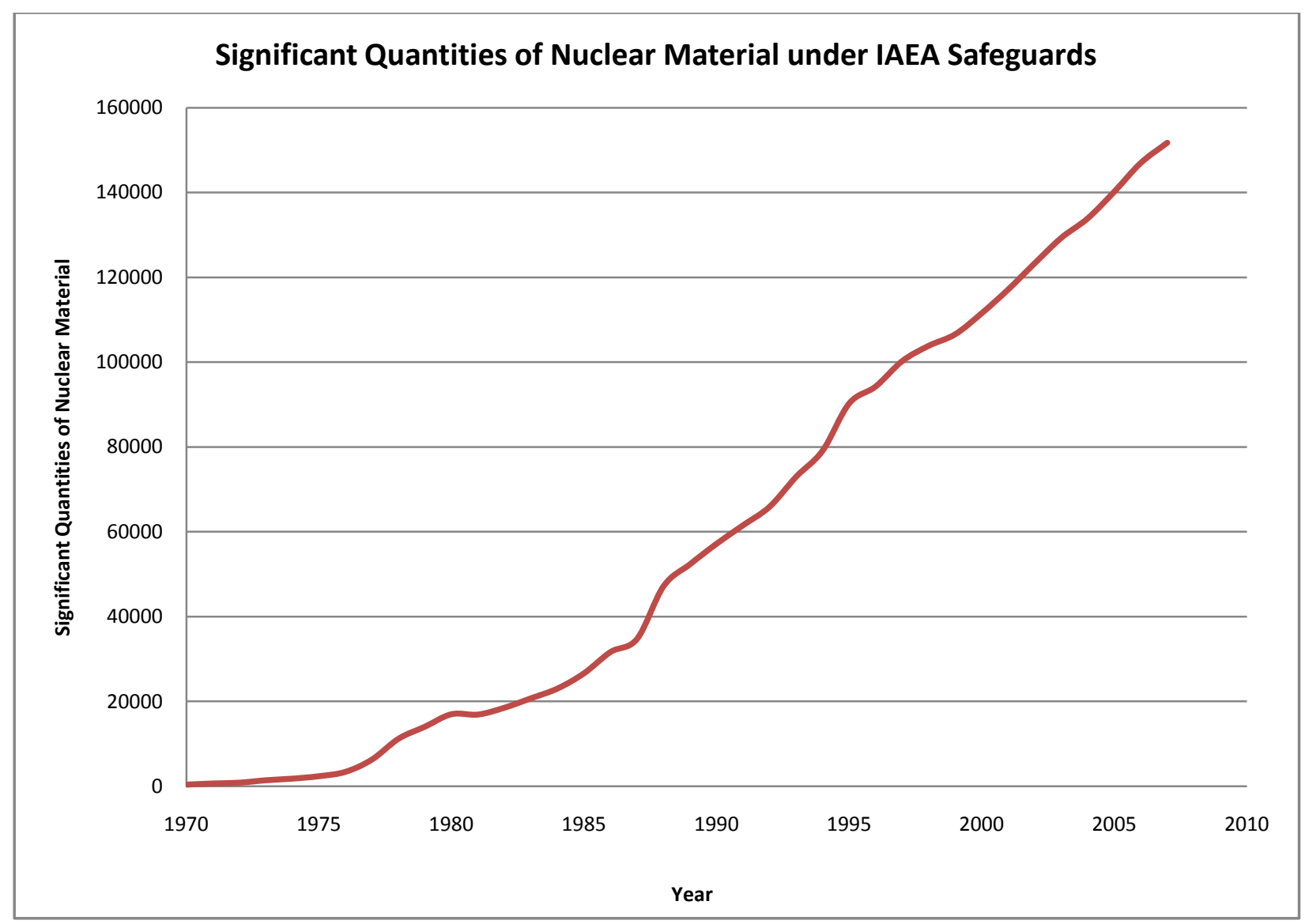

Figure 2: SQs of nuclear material under IAEA safeguards from 1970 to $2007 .^{3}$

\section{Evolution in Safeguards Activities Over Time}

Significant events have caused the safeguards regime of the IAEA to reorganize and strengthen. In 1991, Iraq was found to be in violation of its safeguards agreement, for pursuing a clandestine nuclear weapons program. South Africa signed the Nonproliferation Treaty (NPT) as NNWS in 1991 but later revealed that the country had dismantled a nuclear weapons program just prior to acceding to the NPT. By 1994, after 3 years of inspections, the IAEA confirmed that South Africa had dismantled their weapons program. The Democratic People's Republic of Korea (DPRK) first announced that they would withdraw from the NPT in 1993 followed by international suspicions of a nuclear weapons program, and negotiated agreements to contain and monitor the plutonium production reactor and spent fuel. The DPRK officially withdrew from the NPT in 2003, becoming the first state ever to do so (and its withdrawal has not been accepted by the NPT States party due to procedural oversights). These events prompted the IAEA to compose the Additional Protocol (AP) to the Safeguards Agreements, which provided the IAEA with additional access to information, locations and technical verification measures to aid in the discovery of indicators of undeclared nuclear activities.

Comprehensive safeguards are based on INFCIRC/153 and allow the IAEA to inspect all nuclear material declared by that state. The Additional Protocol (AP), based on INFCIRC/540,

\footnotetext{
${ }^{3}$ Source: IAEA Annual Reports for 1970 to 2007, www.iaea.org/About/Policy/GC/GC51/Agenda/
} 
helps the IAEA to look for undeclared nuclear material or activities. The AP has given the IAEA more access but has also expanded the safeguards system and introduced new resource intensive activities which take place both in Vienna and in the field. Safeguards under the AP include use of short-notice random inspections, unattended remote monitoring, access to all locations on every nuclear site, all locations provided in the expanded declaration, the increased collection of environmental samples, along with other measures. ${ }^{4}$ These activities give the IAEA more responsibility (reaching conclusions about the absence of indicators of undeclared activities in a state) and thus a greater scope of work for its employees.

There are currently 71 states with safeguarded nuclear activities. ${ }^{5}$ Figure 3 shows the breakdown of the AP status for these 71 states. A state with comprehensive safeguards has not yet signed the AP. Once it is signed, the state composes a declaration of all nuclear-related activities and provides it to the IAEA, which is then evaluated for consistency with other information available to the IAEA. Once the AP is put into force, the IAEA takes extra effort to verify that all nuclear activities are declared and remain in peaceful uses. Once this broader conclusion is reached, the state has entered into "integrated safeguards." As of 2009, 18 states have put the AP into force but have not yet reached the broader conclusion. The IAEA must undergo extra effort to verify the nuclear activities of these states. Additionally, 10 more states have signed the AP and plan to put it into force in the near future. ${ }^{6}$

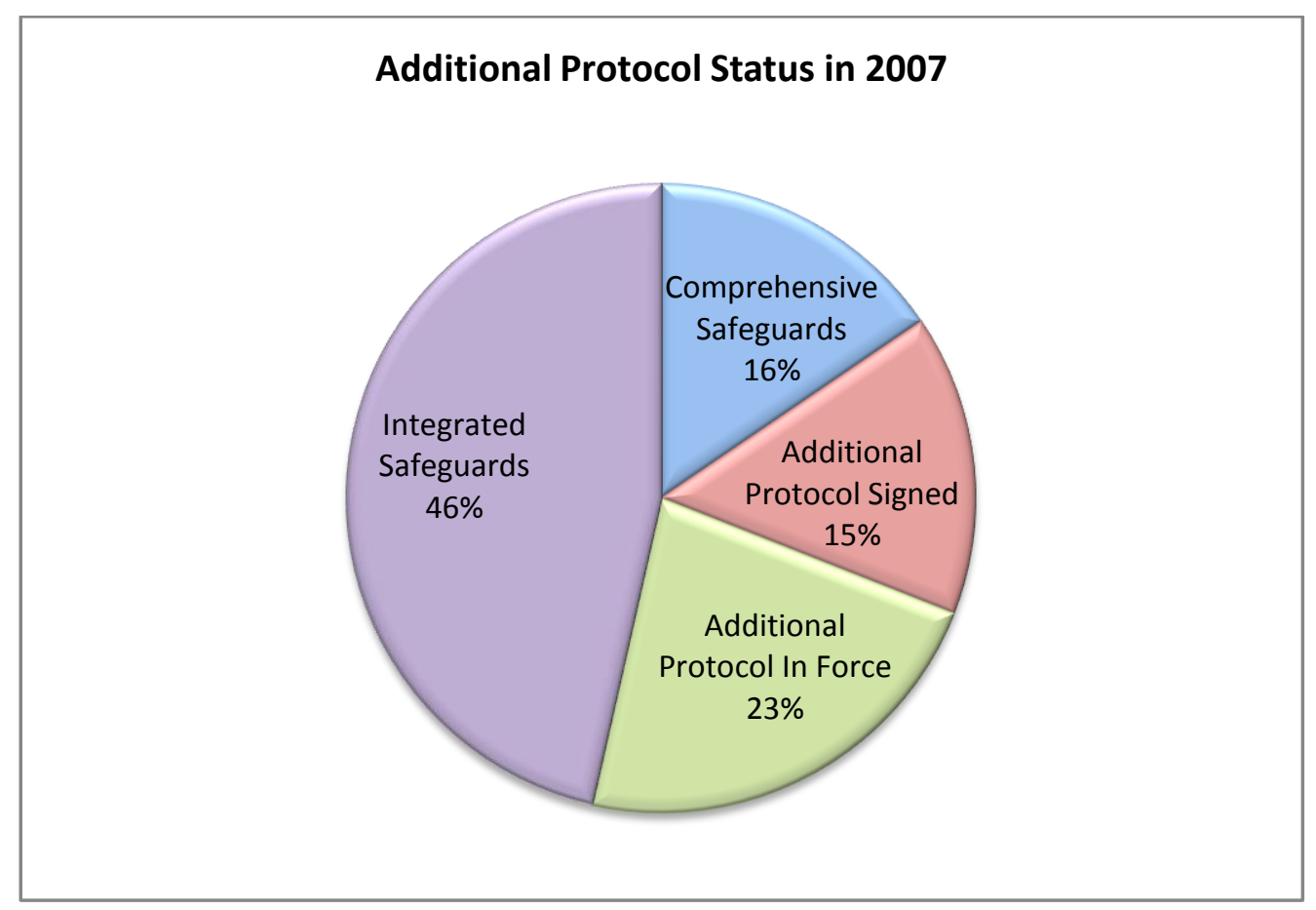

Figure 3: Additional Protocol status as of 2007 in 71 states with safeguarded nuclear activities. ${ }^{7}$

\footnotetext{
${ }^{4}$ Source: IAEA, "IAEA Safeguards: Stemming the Spread of Nuclear Weapons," 2001

${ }^{5}$ Source: IAEA Annual Report for 2007, www.iaea.org/Publications/Reports/Anrep2007/index.html

${ }^{6}$ Source: IAEA Website, "Additional Protocols to Nuclear Safeguards Agreements," July 9, 2009, www.iaea.org/OurWork/SV/Safeguards/sg_protocol.html

${ }^{7}$ Source: IAEA Website, "Additional Protocols to Nuclear Safeguards Agreements," July 20, 2009, www.iaea.org/OurWork/SV/Safeguards/sg_protocol.html
} 
In 2007, there were also a significant number of facilities in states with the AP signed or in force but not yet under integrated safeguards. Figure 4 shows the break down of the number of facilities by the AP status of each state. The AP was first signed in 1997 and grew to having a majority of nuclear facilities under integrated safeguards within 10 years. However, it can be seen that this transformation from comprehensive to integrated safeguards has had an impact on on the IAEA safeguards budget.

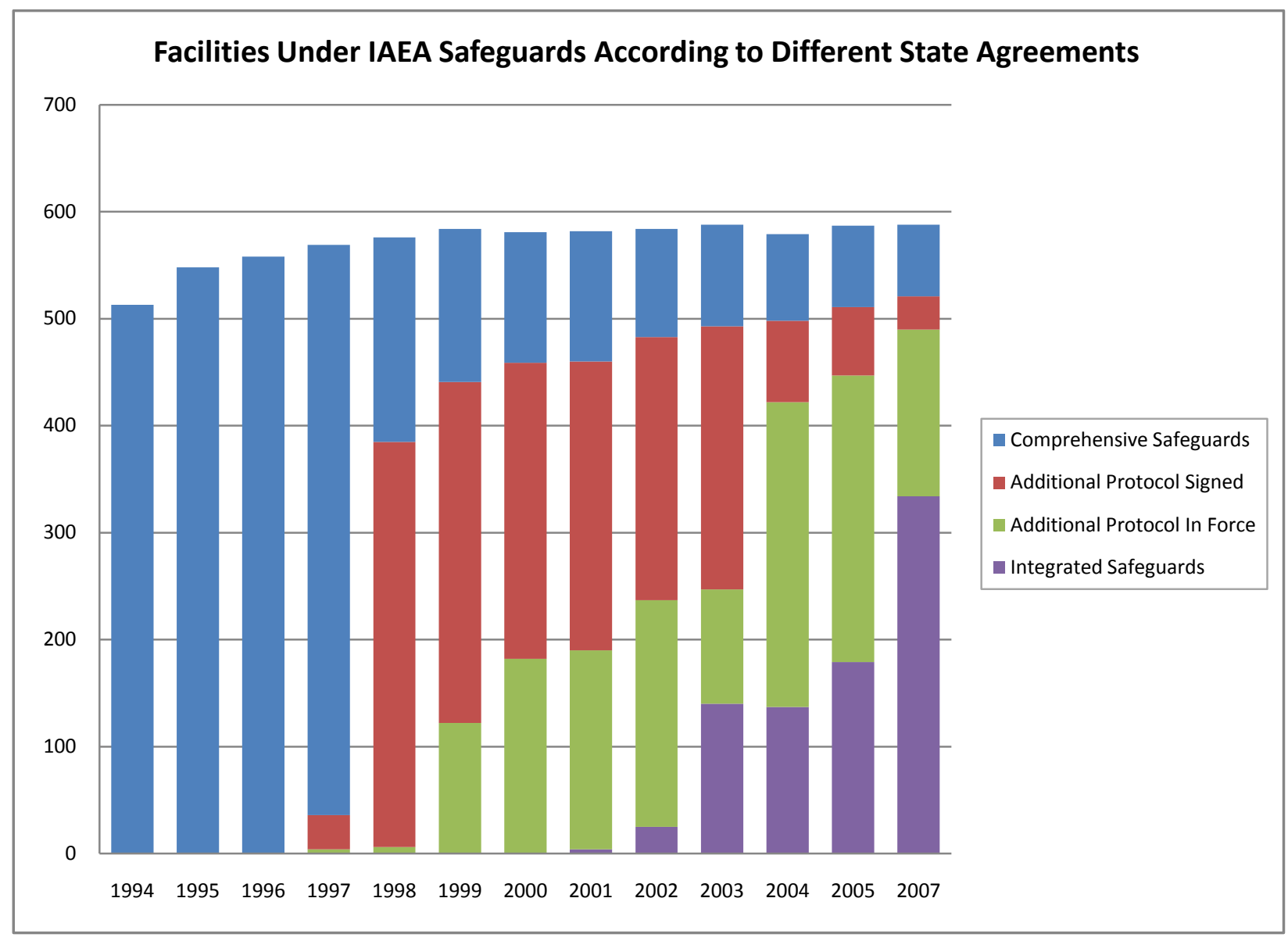

Figure 4: Number of safeguarded nuclear facilities in the world according to AP status of corresponding state. ${ }^{8,9}$ Facilities include power reactors, research reactors, conversion plants, fuel fabrication plants, reprocessing plants, enrichment plants, separate storage facilities, and other facilities, according to the IAEA Annual Reports.

\section{Future Projection of Safeguarded Facilities and Nuclear Material}

As the demand for electricity increases in both industrialized and developing nations, many countries are looking into creating or expanding their nuclear energy infrastructure. Figure 5 shows the LWR and HWR plants under IAEA safeguards from 1970 to 2007. The World

\footnotetext{
${ }^{8}$ Source: IAEA Annual Reports for 1994 to 2007, www.iaea.org/Publications/Reports/Anrep2007/index.html

${ }^{9}$ Source: IAEA Website, "Additional Protocols to Nuclear Safeguards Agreements," July 20, 2009, www.iaea.org/OurWork/SV/Safeguards/sg_protocol.html
} 
Nuclear Association provides information on countries that have new plants under construction or are planning to build more in the future. Assuming that all plans for power plants succeed and that safeguards activities begin as the plants are put online (in reality, they begin much earlier), a projection is made of how many plants in NNWS will be eligible for safeguards through 2030. This projection includes existing plants in India that are eligible and expected to be under IAEA safeguards in the near future. It is assumed that all existing plants remain under safeguards (which they usually do, even after being decommissioned) or that the state replaces lost nuclear capacity with a new nuclear plant. Figure 5 shows that the number of plants will more than double in about 20 years. There will also be nearly twice as many HWR plants, which, as mentioned before, take more effort to safeguard due to the heightened possibility of diversion of nuclear material.

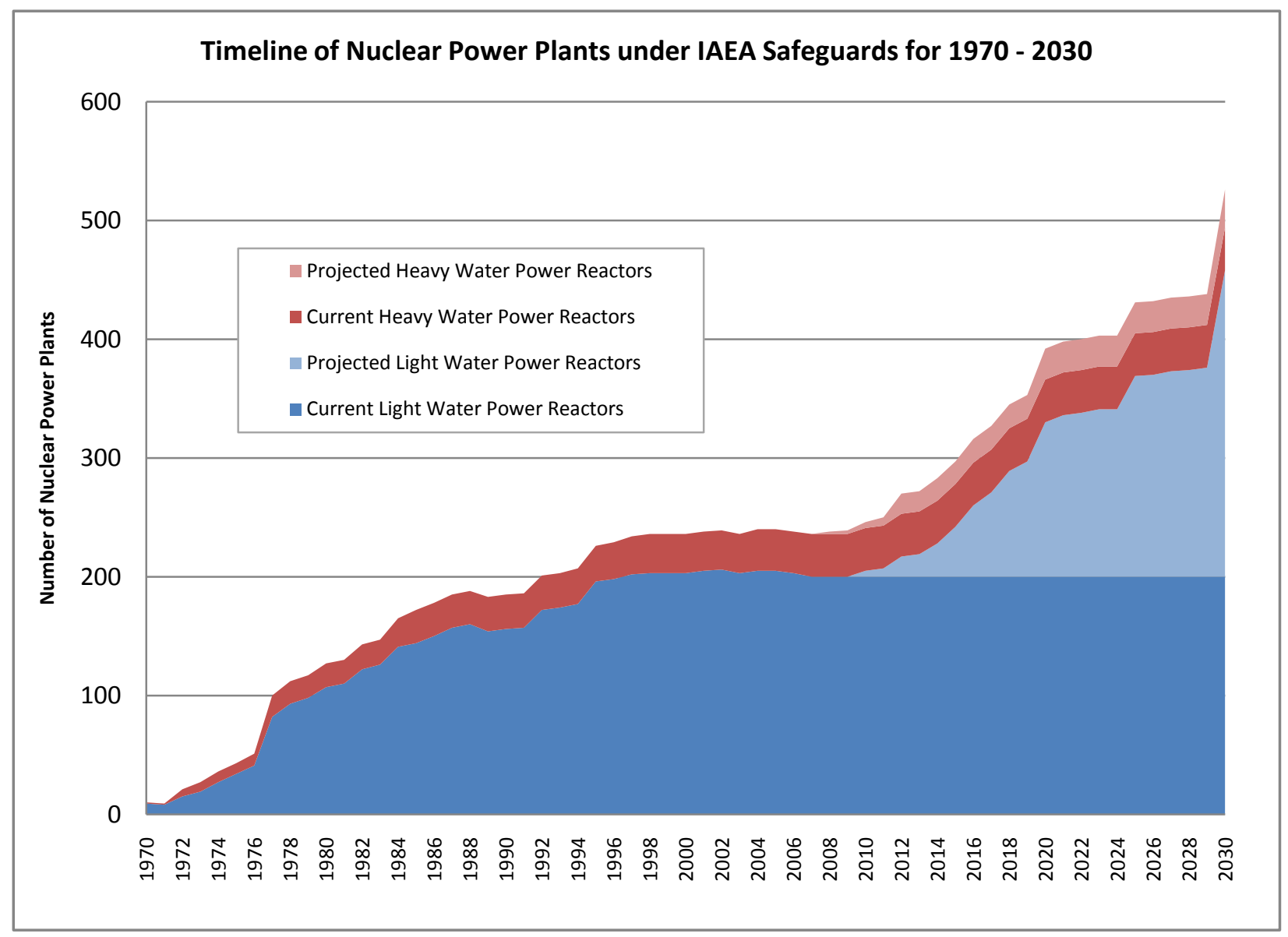

Figure 5: Past and present number of nuclear power plants under IAEA safeguards ${ }^{10}$ and projected number of LWR and HWR plants under IAEA safeguards until $2030 .{ }^{11}$

\footnotetext{
${ }^{10}$ Source for years 1970-2007: IAEA Annual Reports, 1970-2007: www.iaea.org/About/Policy/GC/GC51/Agenda/

${ }^{11}$ Source for years 2008-2030: World Nuclear Association, Country Briefings, 2009, www.worldnuclear.org/info/default.aspx
} 
In order to support the expansion of nuclear power, new fuel cycle facilities will also add to the number of facilities eligible for IAEA safeguards in the future. The nuclear weapons states (NWS) are heavily planning to upgrade current plants and build new conversion, enrichment, and fuel fabrication plants to match the world-wide expansion of nuclear power. ${ }^{12}$ Therefore, a list of current and planned facilities in NNWS eligible for IAEA safeguards is used for future projections, as shown in Table 1. An operation date of 2030 is assumed as the latest if no other information is given. Pakistan is included in these projections because it has the potential to be under safeguards. Also, there have been no new plans to built reprocessing plants by NNWS. These facilities ${ }^{13}$, along with the projected number of plants in Figure 5 are combined to show the total growth in number of safeguarded facilities from 1970 to 2030 in Figure 6. Once again, the number of facilities under IAEA safeguards is expected to double in the next 20 years.

Table 1: List of current and projected nuclear facilities eligible for IAEA Safeguards until 2030 $14,15,16$

\begin{tabular}{lllll}
\hline Country & Facility Name & Facility Type & Facility Status & Operation \\
\hline Australia & Uranium Enrichment Facility & Enrichment Plant & Planned & 2015 \\
Azerbaijan & Research Reactor & Research Reactor & Planned & 2012 \\
Brazil & Fabrica de Combustivel Nuclear & Conversion to UO2 & In operation & Current \\
\hline Iran & Isfahan Nuclear Fuel Plant & Fuel Fabrication & Commissioning & 2010 \\
Kazakhstan & Ulba Conversion Plant & Conversion to UF6 & Planned & 2030 \\
\hline Kazakhstan & Ulba Fuel Fabrication Plant & Fuel Fabrication & Planned & 2030 \\
Pakistan & Islamabad & Conversion to UO2 & In operation & Current \\
\hline Pakistan & Uranium Enrichment Facility & Conversion to UF7 & Planned & 2013 \\
Pakistan & Kahuta & Enrichment Plant & In operation & Current \\
\hline Pakistan & Uranium Enrichment Facility & Enrichment Plant & Planned & 2013 \\
Pakistan & Fuel Fabrication Facility & Fuel Fabrication & Planned & 2013 \\
\hline South Africa & Enrichment Plant & Enrichment Plant & Planned & 2017 \\
\hline Turkey & Enrichment Plant & Enrichment Plant & Planned & 2030 \\
\hline
\end{tabular}

\footnotetext{
${ }^{12}$ Source: WISE Uranium Project, “Uranium Enrichment and Fuel Fabrication,” 2009, www.wiseuranium.org/indexe.html

${ }^{13}$ Facilities in Figure 6 do not include research reactors because the future increase is insignificant.

${ }^{14}$ Source: WISE Uranium Project, "Uranium Enrichment and Fuel Fabrication," 2009, www.wiseuranium.org/indexe.html

${ }^{15}$ Source: IAEA Nuclear Fuel Cycle Information System, 2007, wwwnfcis.iaea.org/NFCIS/NFCISMain.asp?Order=1\&RPage=1\&Page=1\&RightP=List

${ }^{16}$ Source: World Nuclear Association, Country Briefings, 2009, www.world-nuclear.org/info/default.aspx
} 


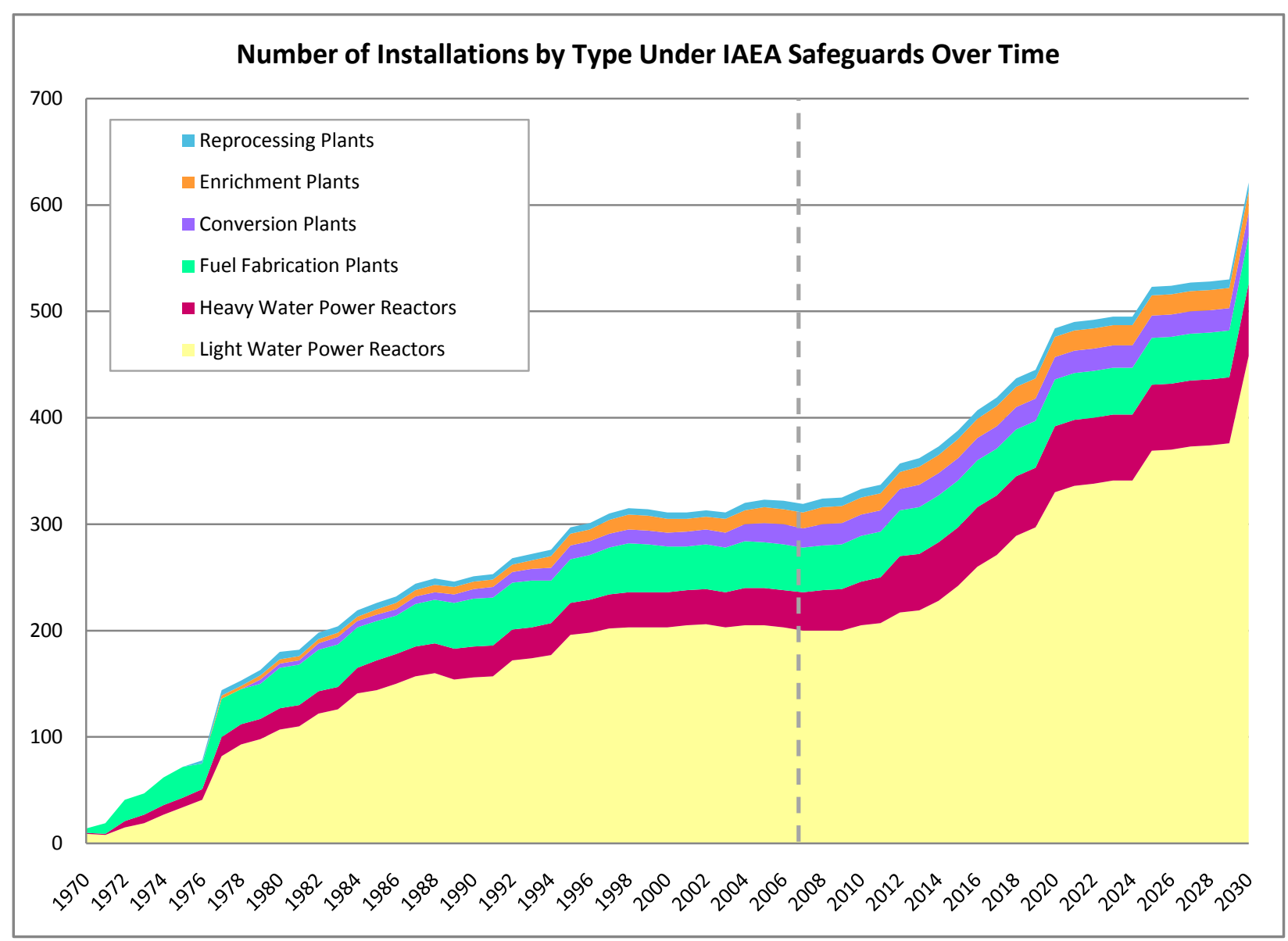

Figure 6: Past and present numbers of different types of installations under safeguards for 1970 to $2007^{17}$ and projected numbers of nuclear facilities until 2030. ${ }^{18,19,20}$ The past and future projections are separated by the dotted line.

In order to estimate the amount of nuclear material that will be under IAEA safeguards to support the growing nuclear industry, a projection of the nuclear energy electric capacity must be estimated. While documenting the planned power plants from the World Nuclear Association, the planned capacity was also calculated. If there was no planned capacity available, then it was assumed that each new unit in a plant would be 1 GWe capacity for LWRs and $500 \mathrm{MWe}$ capacity for HWRs, which are rough average capacities for the new LWR and HWR plants being constructed. This information was then used to create Figure 7, which expands the projected capacity from the current nuclear capacity under safeguards. The nuclear capacity for safeguarded power plants is expected to nearly triple.

\footnotetext{
${ }^{17}$ Source: IAEA Annual Reports, 1970-2007: www.iaea.org/About/Policy/GC/GC51/Agenda/

18 Source: World Nuclear Association, Country Briefings, 2009, www.world-nuclear.org/info/default.aspx

${ }^{19}$ Source: IAEA Nuclear Fuel Cycle Information System, 2007, wwwnfcis.iaea.org/NFCIS/NFCISMain.asp?Order=1\&RPage=1\&Page=1\&RightP=List

${ }^{20}$ Source: WISE Uranium Project, "Uranium Enrichment and Fuel Fabrication,” 2009, www.wiseuranium.org/indexe.html
} 


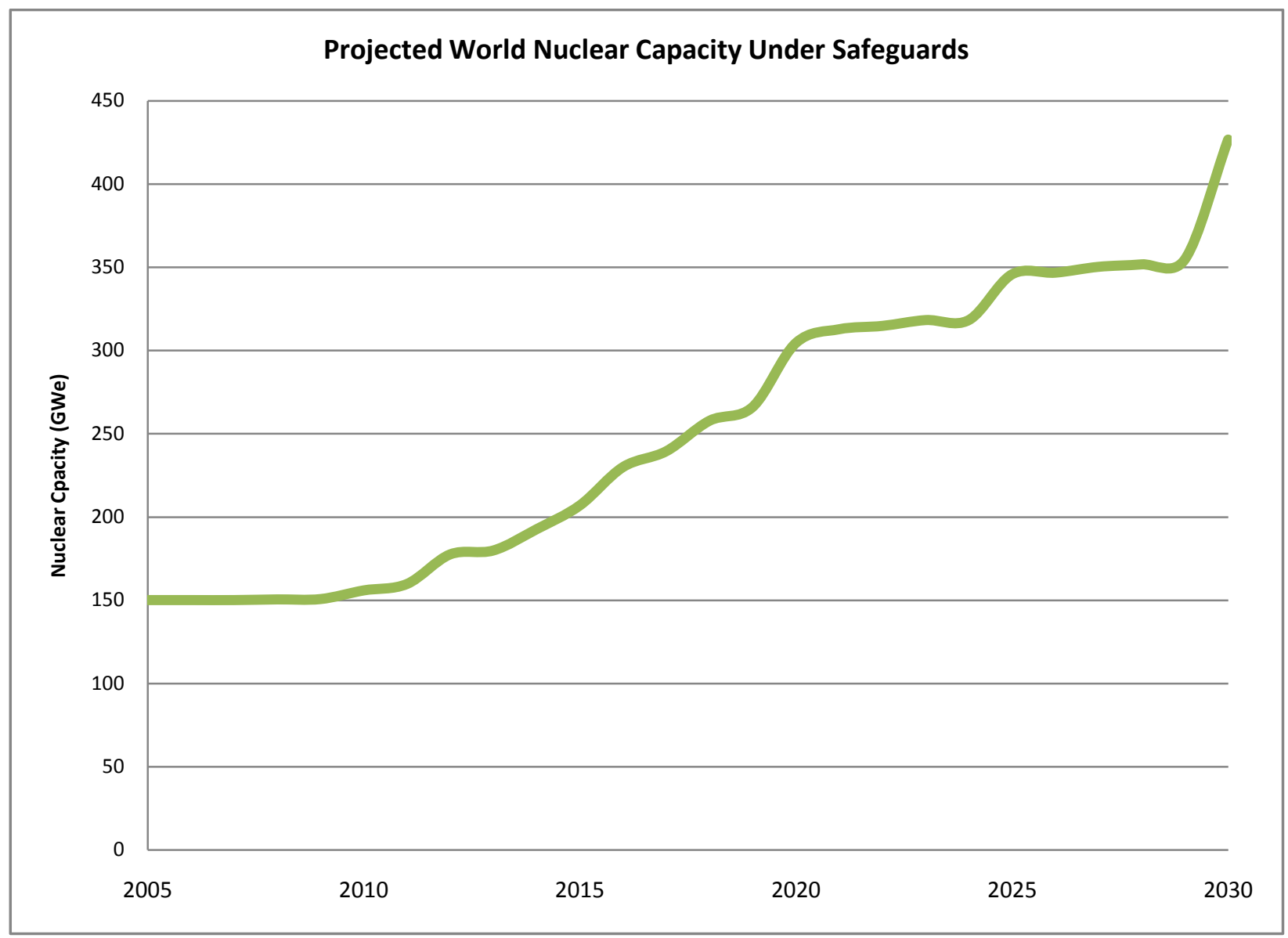

Figure 7: Projected world electric capacity for planned nuclear power plants in NNWS eligible for safeguards ${ }^{21,22}$

With the projected capacities of nuclear power in Figure 7, the amount of nuclear material to support it can now be calculated. 245 tons of yellow cake is needed per year to supply the fuel for 1 GWe capacity of a nuclear reactor, which is equal to 208 tons of the element uranium. $^{23}$ Table 2 shows the assumed parameters for SQs and concentrations of U-235 and Pu at the various points in the fuel cycle. Table 3 shows the SQs per 1 GWe capacity of LWR and HWR plants used in the once-through fuel cycle. It is assumed that eventually all nuclear material under safeguards in the fuel cycle will result as the U-235 in tails from conversion, enrichment, and fuel fabrication or as U-235 and Pu in spent fuel. As seen in Table 3, 208 tons of uranium per 1 GWe turns into about 41 SQs for LWRs and 13 SQs for HWRs per GWe per year. More SQs are used for LWRs because there is a large amount of enrichment tail assays that are not present in the HWR fuel cycle since it uses natural uranium. These numbers are used to calculate the number of SQs needed to support the capacity of the projected safeguarded power plants until 2030, as shown in Figure 8. The SQs of material under safeguards is, once again,

\footnotetext{
${ }^{21}$ Source for year 2005 - 2007: IAEA Annual Reports for 2005 to 2007, www.iaea.org/Publications/Reports/Anrep2007/index.html

${ }^{22}$ Source for years 2008 - 2030: World Nuclear Association, Country Briefings, 2009, www.worldnuclear.org/info/default.aspx

${ }^{23}$ Source: WISE Uranium Project, "Nuclear Fuel Material Balance Calculator,” 2003, www.wiseuranium.org/nfcm.html
} 
estimated to almost triple in 20 years. Also, the projected numbers do not include fissile material that will be needed for research facilities in the future.

Table 2: Assumed parameters used for projection of nuclear material needed to sustain projected nuclear power capacity under safeguards. ${ }^{24,25,26}$

\begin{tabular}{lc}
\hline SQ of Pu (total element) in tons & 0.008 \\
SQ of U-235 in LEU (total isotope) in tons & 0.075 \\
\hline Percent of U-235 in Natural U & $0.07 \%$ \\
Percent of U-235 in Enriched U & $4 \%$ \\
\hline Percent of U-235 in Enriched U Tails & $0.25 \%$ \\
Percent of U-235 in LWR Spent Fuel & $1 \%$ \\
Percent of Pu in LWR Spent Fuel & $1 \%$ \\
Percent of U-235 in HWR Spent Fuel & $0.2 \%$ \\
\hline Percent of Pu in HWR Spent Fuel & $0.4 \%$ \\
\hline
\end{tabular}

Table 3: Significant quantities of nuclear material needed to sustain 1 GWe of capacity for LWR and HWR power plants per year, using parameters from Table 2.

\begin{tabular}{lccc}
\hline & Tons of $\mathbf{H M}^{\mathbf{2 7}}$ & SQs for LWR & SQs for HWR \\
\hline Conversion Tails (U) & 1.04 & 0.010 & 0.010 \\
Enrichment Tails (U) & 181.04 & 6.035 & - \\
Fuel Fabrication Tails (U) & 0.26 & 0.137 & 0.002 \\
Spent Fuel (U and Pu) & 25.43 & 35.175 & 12.858 \\
Total & $\mathbf{2 0 7 . 7 7}$ & $\mathbf{4 1 . 3 5 6}$ & $\mathbf{1 2 . 8 7 0}$ \\
\hline
\end{tabular}

\footnotetext{
${ }^{24}$ Source: World Nuclear Association, "Plutonium," 2009, www.world-nuclear.org/info/inf15.html

25 "Reprocessing versus Direct Disposal of Spent CANDU Nuclear Fuel:

A Possible Application of Fluoride Volatility" By D. Rozon and D. Lister, 2008

26 "The Evolution of International Safeguards" - Presentation by Jim Tape, June 2009

${ }^{27}$ Source: WISE Uranium Project, "Nuclear Fuel Material Balance Calculator," 2003, www.wiseuranium.org/nfem.html
} 


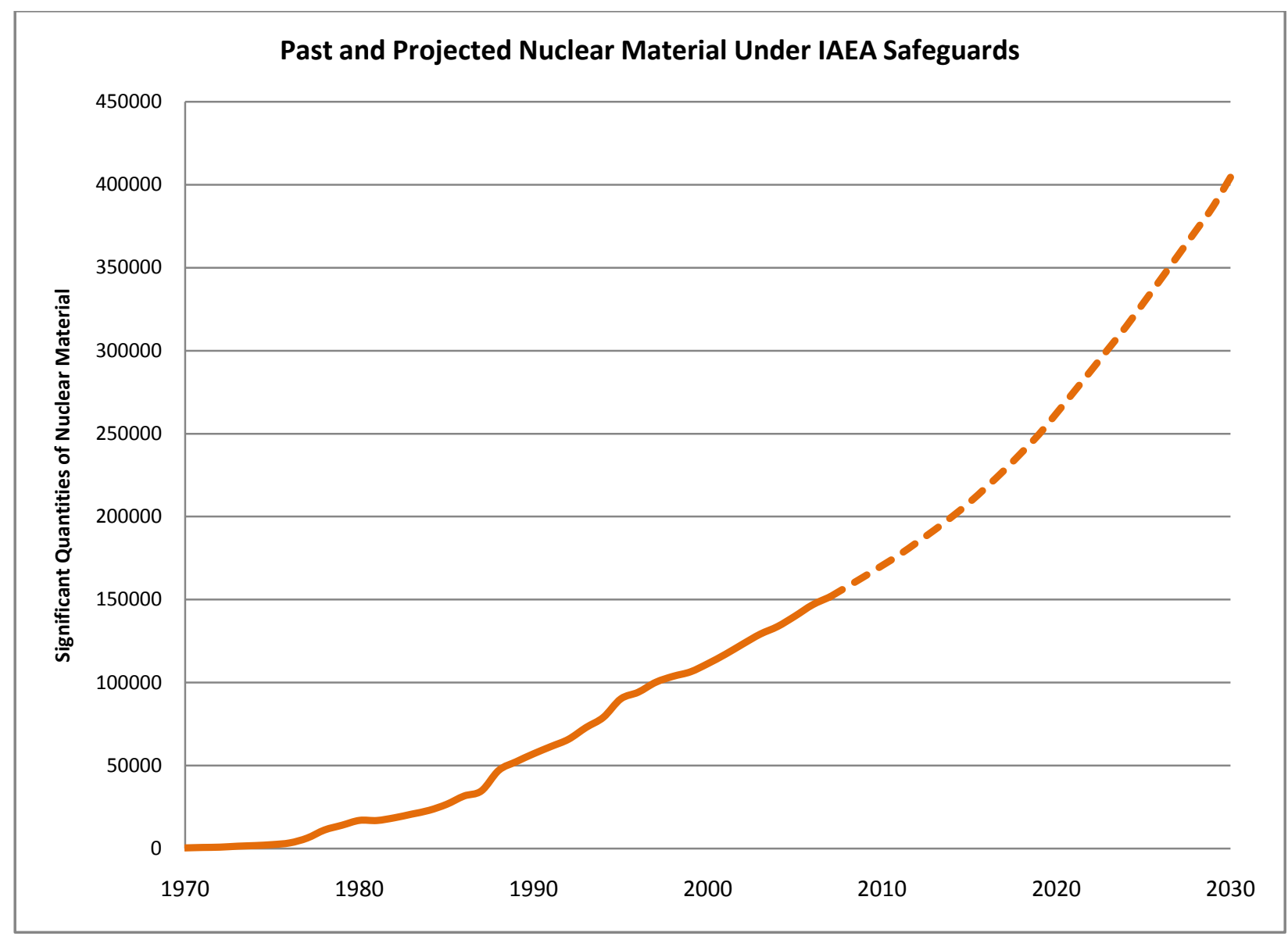

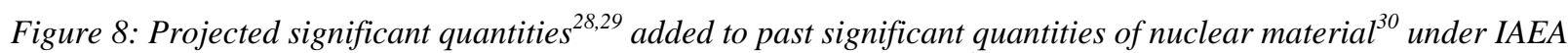
safeguards for 1970 to $2030^{31}$.

\section{Safeguards Budget}

While the IAEA safeguards budget has significantly increased since 1970, the IAEA has expressed concern that its budget may experience zero real growth over the foreseeable future. ${ }^{32}$ Figure 9 shows the IAEA budget in 2008 dollars from 1970 to 2009. The dotted line represents when the IAEA found clandestine nuclear activities in Iraq in 1991. The AP came soon thereafter and the IAEA was taking extra effort to verify states' peaceful nuclear programs, thus resulting in a modest budget increase. Another budget increase came in the mid-2000's when the United States led an effort to provide an approximately $11 \%$ increase in the IAEA's overall budget. It can be seen that the safeguards budget has remained quite steady for the past few years and is not projected to grow.

\footnotetext{
${ }^{28}$ Source: World Nuclear Association, Country Briefings, 2009, www.world-nuclear.org/info/default.aspx

${ }^{29}$ Source: WISE Uranium Project, "Nuclear Fuel Material Balance Calculator,” 2003, www.wiseuranium.org/nfcm.html

${ }^{30}$ Source: IAEA Annual Reports, 1970-2007: www.iaea.org/About/Policy/GC/GC51/Agenda/

${ }^{31}$ Information for 1991 is unavailable, the graph shows an average of 1990 and 1992 for graphical purposes

${ }^{32}$ Source: "Reinforcing the Global Nuclear Order for Peace and Prosperity: The Role of the IAEA to 2020 and

Beyond,” International Atomic Energy Agency, May 2008
} 


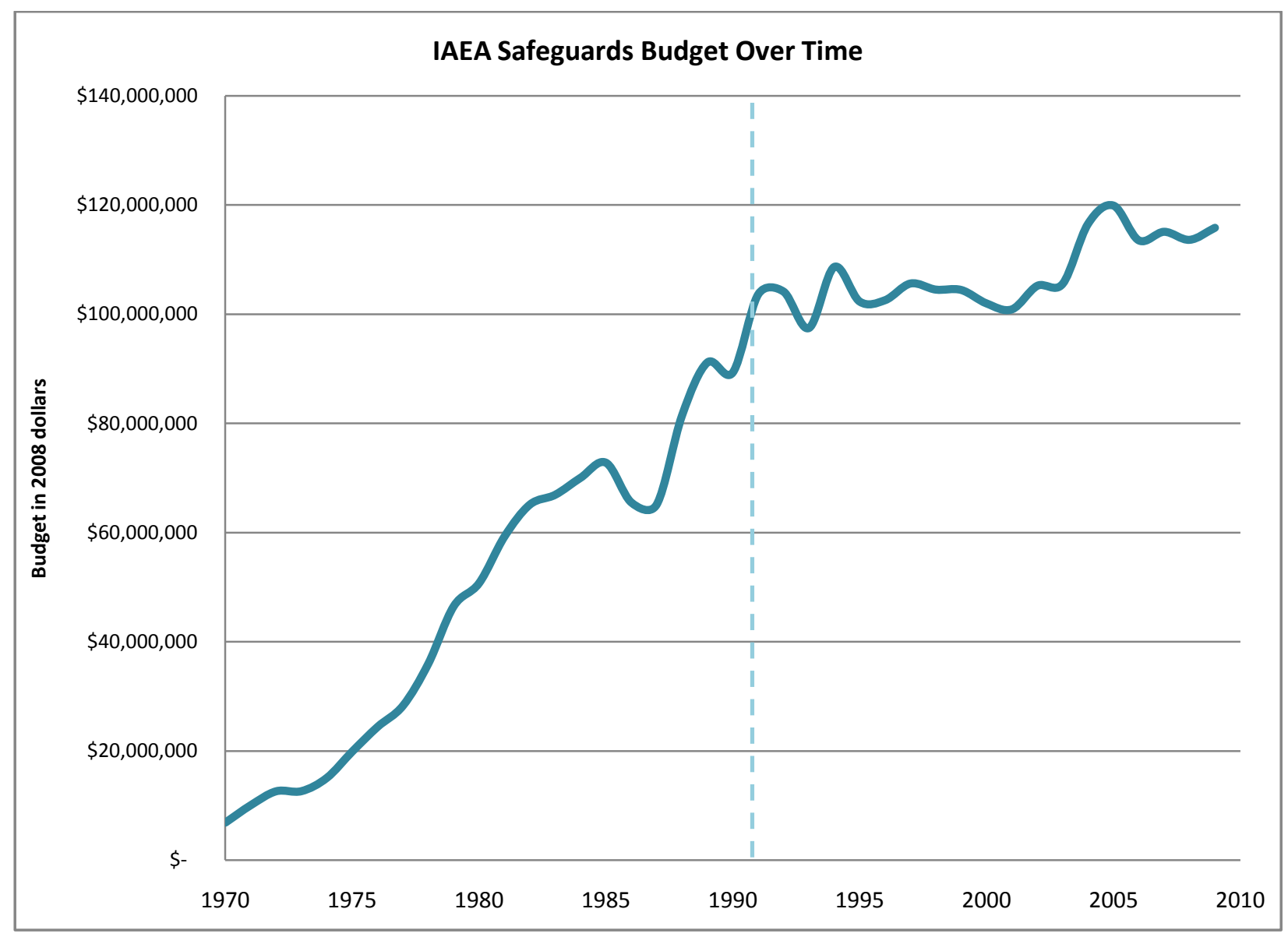

Figure 9: IAEA Safeguards budget from 1970 to 2009, ${ }^{33,34}$ the dotted line represents when clandestine nuclear activities were found in Iraq in 1991.

Using the data from Figure 8 and Figure 9, a timeline of safeguards budget per significant quantity of material is composed. Figure 10 shows that there has been an extreme decline in the safeguards budget available per significant quantity of material under safeguards. The relation is only expected to decline to under $\$ 300$ per SQ by 2030. A zero real growth budget for IAEA safeguards will not be sufficient to safeguard the future nuclear material needed to sustain the growing nuclear power demand.

33 Source: IAEA Annual Reports and Budgets, 1970-2009: www.iaea.org/About/Policy/GC/GC51/Agenda/

${ }^{34}$ Source: Inflation Data .com, 1970-2008, www.inflationdata.com/Inflation/Inflation_Rate/HistoricalInflation.aspx 


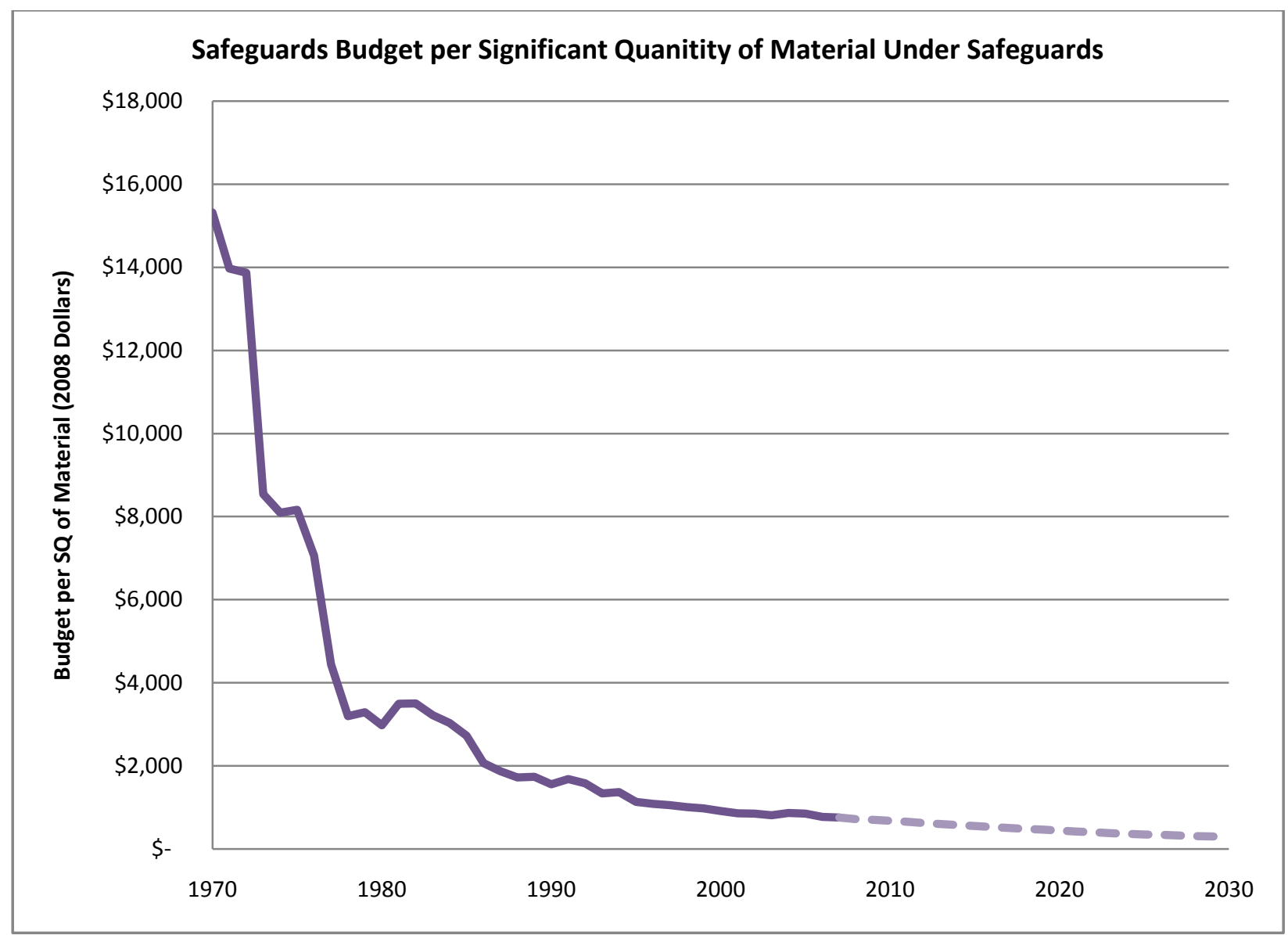

Figure 10: Timeline of safeguards budget per SQ of material for 1970 to 2007 and then projected to 2030 with zero real growth in budget ${ }^{35}$

${ }^{35}$ Data is taken from Figure 8 and Figure 9 


\section{Conclusion}

The IAEA plays a crucial role in international nuclear security by safeguarding fissile material from diversion into non-peaceful uses. The scope of work of the IAEA has increased dramatically over its 50 year life due to increasing nuclear infrastructure and responding to the threat of clandestine nuclear weapons programs. There are currently 71 states with safeguarded nuclear activities, 18 of which are being inspected to reach the broader conclusion and achieve integrated safeguards. The majority of safeguarded nuclear facilities are now under integrated safeguards since the AP was first signed in 1997.

Since nuclear power is an attractive option to meet electric energy needs for both industrialized and developing countries, the safeguards scope of the IAEA is expected to increase rapidly in the coming years. The number of new nuclear power plants in NNWS will more than double by 2030, including a large increase in HWR plants, which are a greater proliferation concern. The total number of nuclear facilities eligible for safeguards will also nearly triple in the next 20 years. The nuclear electric capacity from these new plants will nearly triple the nuclear capacity under safeguards to about 425 GWe. As a result, the significant quantities of nuclear material under IAEA safeguards is expected to nearly triple by 2030 just from the material needed to sustain the new and existing power plants.

The IAEA safeguards budget is expected to see zero real growth in the near future. This would cause the budget to decline to under \$300 per SQ by 2030. As new nuclear power plants and other nuclear facilities are constructed in NNWS, more and more nuclear material will need to be safeguarded by the IAEA. An increase in budget will be necessary for the future of international safeguards and nuclear security. This report has not evaluated the affect of added missions to the IAEA, but if they were to be asked to verify a new treaty or convention, such as a Fissile Material Cutoff Treaty or a Disarmament agreement, the budget pressures would worsen. 


\section{Appendix A}

The table on the next pages shows the facilities under IAEA safeguards or containing safeguarded material by the end of the year $2007 .{ }^{36}$

${ }^{36}$ Source: IAEA Annual Report 2007: www.iaea.org/About/Policy/GC/GC51/Agenda/ 
Table A28. Facilities under Agency Safeguards or Containing Safeguarded Material on 31 December 2007

\begin{tabular}{|c|c|c|}
\hline State $^{a}$ & Name of facility & Locatic \\
\hline \multicolumn{3}{|l|}{ Power reactors } \\
\hline \multirow[t]{2}{*}{ Argentina } & Atucha & Lima \\
\hline & Embalse & Embalse \\
\hline Armenia & Armenia & Metsamor \\
\hline \multirow[t]{6}{*}{ Belgium } & Tihange-1 & Tihange \\
\hline & Tihange-2 & Tihange \\
\hline & Tihange-3 & Tihange \\
\hline & Doel-1 & Doel \\
\hline & Doel-3 & Doel \\
\hline & Doel-4 & Doel \\
\hline \multirow[t]{2}{*}{ Brazil } & Angra-2 & Angra dos Reis \\
\hline & Angra-1 & Angra dos Reis \\
\hline \multirow[t]{3}{*}{ Bulgaria } & Kozloduy-I & Kozloduy \\
\hline & Kozloduy-II & Kozloduy \\
\hline & Kozloduy-III & Kozloduy \\
\hline \multirow[t]{6}{*}{ Canada } & Bruce A & Tiverton \\
\hline & Bruce B & Tiverton \\
\hline & Gentilly-2 & Gentilly \\
\hline & Darlington & Bowmanville \\
\hline & Pickering & Pickering \\
\hline & Point Lepreau & Point Lepreau \\
\hline China & Qin Shan & Hai Yan \\
\hline \multirow[t]{3}{*}{ Czech Republic } & EDU-1 & Dukovany \\
\hline & EDU-2 & Dukovany \\
\hline & Temelin & Temelin \\
\hline \multirow[t]{3}{*}{ Finland } & Loviisa & Loviisa \\
\hline & TVO-I & Olkiluoto \\
\hline & TVO-II & Olkiluoto \\
\hline \multirow[t]{16}{*}{ Germany } & AVR & Jülich \\
\hline & Brunsbüttel & Brunsbüttel \\
\hline & Grohnde & Grohnde \\
\hline & Neckarwestheim-II & Neckarwestheim \\
\hline & Obrigheim & Obrigheim \\
\hline & Biblis-A & Biblis \\
\hline & Biblis-B & Biblis \\
\hline & Emsland & Lingen \\
\hline & Grafenrheinfeld & Grafenrheinfeld \\
\hline & Greifswald- 1 and 2 & Lubmin \\
\hline & Isar-2 & Essenbach \\
\hline & Isar-Ohu & Ohu bei Landshut \\
\hline & Krümmel & Geesthacht \\
\hline & Philippsburg-1 & Philippsburg \\
\hline & Philippsburg-2 & Philippsburg \\
\hline & Brokdorf & Brokdorf \\
\hline
\end{tabular}




\begin{tabular}{|c|c|c|}
\hline State $^{\mathrm{a}}$ & Name of facility & Location $^{\mathrm{a}}$ \\
\hline & Gundremmingen-B & Gundremmingen \\
\hline & Gundremmingen-C & Gundremmingen \\
\hline & Unterweser & Unterweser \\
\hline & Neckarwestheim & Neckarwestheim \\
\hline & Thorium Hochtemperatur Reaktor & Hamm \\
\hline \multirow[t]{2}{*}{ Hungary } & Paks-I (units 1 and 2) & Paks \\
\hline & Paks-II (units 3 and 4) & Paks \\
\hline \multirow[t]{3}{*}{ India } & KKNP & Kudankulam \\
\hline & RAPS & Rajasthan \\
\hline & TAPS & Tarapur \\
\hline Iran, Islamic Republic of & Bushehr & Halilem \\
\hline \multirow[t]{3}{*}{ Italy } & ENEL-Trino & Trino-Vercellese \\
\hline & ENEL-Caorso & Caorso \\
\hline & ENEL-Latina & Borgo-Sabotino \\
\hline \multirow[t]{38}{*}{ Japan } & Joyo & Higashi-gun, Ibaraki-ken \\
\hline & Fukushima Dai-ichi-2 & Futaba-gun, Fukushima-ken \\
\hline & Fukushima Dai-ichi-3 & Futaba-gun, Fukushima-ken \\
\hline & Fukushima Dai-ichi-6 & Futaba-gun, Fukushima-ken \\
\hline & Fukushima Dai-ichi-1 & Futaba-gun, Fukushima-ken \\
\hline & Fukushima Dai-ichi-4 & Futaba-gun, Fukushima-ken \\
\hline & Fukushima Dai-ichi-5 & Futaba-gun, Fukushima-ken \\
\hline & Fukushima Dai-ni-1 & Futaba-gun, Fukushima-ken \\
\hline & Fukushima Dai-ni-2 & Futaba-gun, Fukushima-ken \\
\hline & Fukushima Dai-ni-3 & Futaba-gun, Fukushima-ken \\
\hline & Fukushima Dai-ni-4 & Futaba-gun, Fukushima-ken \\
\hline & Genkai-1 & Higashimatsuura-gun, Saga-ken \\
\hline & Genkai-2 & Higashimatsuura-gun, Saga-ken \\
\hline & Genkai-3 & Higashimatsuura-gun, Saga-ken \\
\hline & Genkai-4 & Higashimatsuura-gun, Saga-ken \\
\hline & Hamaoka-1 & Ogasa-gun, Shizuoka-ken \\
\hline & Hamaoka-2 & Ogasa-gun, Shizuoka-ken \\
\hline & Hamaoka-3 & Ogasa-gun, Shizuoka-ken \\
\hline & Hamaoka-4 & Ogasa-gun, Shizuoka-ken \\
\hline & Hamaoka-5 & Ogasa-gun, Shizuoka-ken \\
\hline & Higashidori-1 & Shimokita-gun, Aomori-ken \\
\hline & Ikata-1 & Nishiuwa-gun, Ehime-ken \\
\hline & Ikata-2 & Nishiuwa-gun, Ehime-ken \\
\hline & Ikata-3 & Nishiuwa-gun, Ehime-ken \\
\hline & Kashiwazaki-Kariwa-2 & Kashiwazaki-shi, Niigata-ken \\
\hline & Kashiwazaki-Kariwa-3 & Kashiwazaki-shi, Niigata-ken \\
\hline & Kashiwazaki-Kariwa-4 & Kashiwazaki-shi, Niigata-ken \\
\hline & Kashiwazaki-Kariwa-5 & Kashiwazaki-shi, Niigata-ken \\
\hline & Kashiwazaki-Kariwa-1 & Kashiwazaki-shi, Niigata-ken \\
\hline & Kashiwazaki-Kariwa-6 & Kashiwazaki-shi, Niigata-ken \\
\hline & Kashiwazaki-Kariwa-7 & Kashiwazaki-shi, Niigata-ken \\
\hline & Mihama-1 & Mikata-gun, Fukui-ken \\
\hline & Mihama-2 & Mikata-gun, Fukui-ken \\
\hline & Mihama-3 & Mikata-gun, Fukui-ken \\
\hline & Ohi-3 & Ohi-gun, Fukui-ken \\
\hline & Ohi-4 & Ohi-gun, Fukui-ken \\
\hline & Ohi-1 and 2 & Ohi-gun, Fukui-ken \\
\hline & Onagawa-1 & Oshika-gun, Miyagi-ken \\
\hline
\end{tabular}




\begin{tabular}{|c|c|c|}
\hline State $^{a}$ & Name of facility & Location $^{\mathrm{a}}$ \\
\hline & Onagawa-2 & Oshika-gun, Miyagi-ken \\
\hline & Onagawa-3 & Oshika-gun, Miyagi-ken \\
\hline & Fugen & Tsuruga-shi, Fukui-ken \\
\hline & Monju & Tsuruga-shi, Fukui-ken \\
\hline & Sendai-1 & Sendai-shi, Kagoshima-ken \\
\hline & Sendai-2 & Sendai-shi, Kagoshima-ken \\
\hline & Shika-1 & Hakui-gun, Ishikawa-ken \\
\hline & Shika-2 & Hakui-gun, Ishikawa-ken \\
\hline & Shimane-1 & Yatsuka-gun, Shimane-ken \\
\hline & Shimane-2 & Yatsuka-gun, Shimane-ken \\
\hline & Takahama-1 & Ohi-gun, Fukui-ken \\
\hline & Takahama-2 & Ohi-gun, Fukui-ken \\
\hline & Takahama-3 & Ohi-gun, Fukui-ken \\
\hline & Takahama-4 & Ohi-gun, Fukui-ken \\
\hline & Tokai-2 & Tokai-mura, Ibaraki-ken \\
\hline & Tomari-1 & Furuu-gun, Hokkaido \\
\hline & Tomari-2 & Furuu-gun, Hokkaido \\
\hline & Tsuruga-1 & Tsuruga-shi, Fukui-ken \\
\hline & Tsuruga-2 & Tsuruga-shi, Fukui-ken \\
\hline Kazakhstan & $\mathrm{BN}-350$ & Aktau \\
\hline \multirow[t]{20}{*}{ Korea, Republic of } & Kori-1 & Pusan \\
\hline & Kori-2 & Pusan \\
\hline & Kori-3 & Pusan \\
\hline & Kori-4 & Pusan \\
\hline & Ulchin-1 & Ulchin \\
\hline & Ulchin-2 & Ulchin \\
\hline & Ulchin-3 & Ulchin \\
\hline & Ulchin-4 & Ulchin \\
\hline & Ulchin-5 & Ulchin \\
\hline & Ulchin-6 & Ulchin \\
\hline & Wolsong-1 & Kyongju \\
\hline & Wolsong-2 & Kyongju \\
\hline & Wolsong-3 & Kyongju \\
\hline & Wolsong-4 & Kyongju \\
\hline & Younggwang-1 & Younggwang \\
\hline & Younggwang-2 & Younggwang \\
\hline & Younggwang-3 & Younggwang \\
\hline & Younggwang-4 & Younggwang \\
\hline & Younggwang-5 & Younggwang \\
\hline & Younggwang-6 & Younggwang \\
\hline Lithuania & Ignalina & Visaginas \\
\hline \multirow[t]{2}{*}{ Mexico } & Laguna Verde 1 & Alto Lucero \\
\hline & Laguna Verde 2 & Alto Lucero \\
\hline Netherlands & Borssele & Borssele \\
\hline \multirow[t]{2}{*}{ Pakistan } & Chashma-1 & Kundian \\
\hline & Karachi & Karachi \\
\hline \multirow[t]{2}{*}{ Romania } & Cernavoda-1 & Cernavoda \\
\hline & Cernavoda-2 & Cernavoda \\
\hline
\end{tabular}




\begin{tabular}{|c|c|c|}
\hline State $^{a}$ & Name of facility & Location $^{\mathrm{a}}$ \\
\hline Slovakia & $\begin{array}{l}\text { Mochovce EM0-1 } \\
\text { Bohunice-1 } \\
\text { Bohunice-2 }\end{array}$ & $\begin{array}{l}\text { Mochovce } \\
\text { Bohunice } \\
\text { Bohunice }\end{array}$ \\
\hline Slovenia & Krško & Krško \\
\hline South Africa & $\begin{array}{l}\text { Koeberg-1 } \\
\text { Koeberg-2 }\end{array}$ & $\begin{array}{l}\text { Cape Town } \\
\text { Cape Town }\end{array}$ \\
\hline Spain & $\begin{array}{l}\text { Santa María de Garona } \\
\text { José Cabrera } \\
\text { Almaraz-1 } \\
\text { Almaraz-2 } \\
\text { Cofrentes } \\
\text { Asco-1 } \\
\text { Asco-2 } \\
\text { Vandellòs-2 } \\
\text { Trillo-1 } \\
\text { Vandellòs-1 }\end{array}$ & $\begin{array}{l}\text { Santa María de Garona } \\
\text { Almonacid de Zorita } \\
\text { Almaraz } \\
\text { Almaraz } \\
\text { Cofrentes } \\
\text { Asco } \\
\text { Asco } \\
\text { Vandellòs } \\
\text { Trillo } \\
\text { Vandellòs }\end{array}$ \\
\hline Sweden & $\begin{array}{l}\text { Forsmark-1 } \\
\text { Forsmark-2 } \\
\text { Forsmark-3 } \\
\text { Oskarshamn-1 } \\
\text { Oskarshamn-2 } \\
\text { Oskarshamn-3 } \\
\text { Ringhals-1 } \\
\text { Ringhals-2 } \\
\text { Ringhals-3 } \\
\text { Ringhals-4 }\end{array}$ & $\begin{array}{l}\text { Östhammar } \\
\text { Östhammar } \\
\text { Östhammar } \\
\text { Oskarshamn } \\
\text { Oskarshamn } \\
\text { Oskarshamn } \\
\text { Ringhals } \\
\text { Ringhals } \\
\text { Ringhals } \\
\text { Ringhals }\end{array}$ \\
\hline Switzerland & $\begin{array}{l}\text { Mühleberg } \\
\text { Beznau-I } \\
\text { Beznau-II } \\
\text { Gösgen } \\
\text { Leibstadt }\end{array}$ & $\begin{array}{l}\text { Mühleberg } \\
\text { Beznau } \\
\text { Beznau } \\
\text { Gösgen-Däniken } \\
\text { Leibstadt }\end{array}$ \\
\hline Ukraine & $\begin{array}{l}\text { Chernobyl } \\
\text { Khmelnitski-1 } \\
\text { Khmelnitski-2 } \\
\text { Rovno-3 } \\
\text { Rovno-4 } \\
\text { Rovno-1 and 2 } \\
\text { South Ukraine } 1 \\
\text { South Ukraine } 2 \\
\text { South Ukraine } 3 \\
\text { Zaporozhe-1 } \\
\text { Zaporozhe-2 } \\
\text { Zaporozhe-3 } \\
\text { Zaporozhe-4 } \\
\text { Zaporozhe-5 } \\
\text { Zaporozhe-6 }\end{array}$ & $\begin{array}{l}\text { Chernobyl } \\
\text { Neteshin } \\
\text { Neteshin } \\
\text { Kuznetsovsk } \\
\text { Kuznetsovsk } \\
\text { Kuznetsovsk } \\
\text { Yuzhnoukrainsk } \\
\text { Yuzhnoukrainsk } \\
\text { Yuzhnoukrainsk } \\
\text { Energodar } \\
\text { Energodar } \\
\text { Energodar } \\
\text { Energodar } \\
\text { Energodar } \\
\text { Energodar }\end{array}$ \\
\hline
\end{tabular}




\begin{tabular}{|c|c|c|}
\hline State $^{a}$ & Name of facility & Locatio \\
\hline \multicolumn{3}{|c|}{ Research reactors and critical assemblies } \\
\hline Algeria & $\begin{array}{l}\text { Es Salam research reactor } \\
\text { NUR research reactor }\end{array}$ & $\begin{array}{l}\text { Ain Oussera } \\
\text { Wilaya de Tipaza }\end{array}$ \\
\hline Argentina & $\begin{array}{l}\text { Argentine reactor-8 } \\
\text { Argentine reactor-0 } \\
\text { Argentine reactor-1 } \\
\text { Argentine reactor-3 } \\
\text { Argentine reactor-4 } \\
\text { Argentine reactor-6 }\end{array}$ & $\begin{array}{l}\text { Pilcaniyeu } \\
\text { Córdoba } \\
\text { Constituyentes } \\
\text { Ezeiza } \\
\text { Rosario } \\
\text { Bariloche }\end{array}$ \\
\hline Australia & $\begin{array}{l}\text { HIFAR } \\
\text { MOATA } \\
\text { OPAL }\end{array}$ & $\begin{array}{l}\text { Lucas Heights } \\
\text { Lucas Heights } \\
\text { Lucas Heights }\end{array}$ \\
\hline Austria & $\begin{array}{l}\text { Atominstitut der Österreichischen } \\
\text { Universitäten }\end{array}$ & Vienna \\
\hline Bangladesh & $\begin{array}{l}\text { Atomic Energy Research } \\
\text { Establishment }\end{array}$ & Dhaka \\
\hline Belarus & Sosny & Minsk \\
\hline Belgium & $\begin{array}{l}\text { BR1-CEN } \\
\text { BR2/BR02 } \\
\text { Venus } \\
\text { Thetis }\end{array}$ & $\begin{array}{l}\text { Mol } \\
\text { Mol } \\
\text { Mol } \\
\text { Gent }\end{array}$ \\
\hline Brazil & $\begin{array}{l}\text { Argonaut reactor } \\
\text { Critical unit IPEN/MB-01 } \\
\text { IEA-R1 } \\
\text { IPR-R1 CDTN }\end{array}$ & $\begin{array}{l}\text { Rio de Janeiro } \\
\text { São Paulo } \\
\text { São Paulo } \\
\text { Belo Horizonte }\end{array}$ \\
\hline Bulgaria & IRT-2000 & Sofia \\
\hline Canada & $\begin{array}{l}\text { Dalhousie University Slowpoke } \\
\text { DIF } \\
\text { Health Sciences, Chemistry, Reactor } \\
\text { Physics, Fuel Engineering and } \\
\text { Manufacturing } \\
\text { McMaster } \\
\text { NRU } \\
\text { NRX } \\
\text { Slowpoke de l'École Polytechnique } \\
\text { Saskatckewan Slowpoke } \\
\text { Slowpoke-2 Facility at the Royal } \\
\text { Military College of Canada } \\
\text { University of Alberta Slowpoke }\end{array}$ & $\begin{array}{l}\text { Hamilton } \\
\text { Chalk River } \\
\text { Chalk River } \\
\text { Montreal } \\
\text { Saskatoon } \\
\text { Kingston } \\
\text { Edmonton }\end{array}$ \\
\hline Chile & $\begin{array}{l}\text { La Reina } \\
\text { Lo Aguirre }\end{array}$ & $\begin{array}{l}\text { Santiago } \\
\text { Santiago }\end{array}$ \\
\hline China & HTGR & Nankou \\
\hline Colombia & IAN-R1 & Bogotá \\
\hline
\end{tabular}




\begin{tabular}{|c|c|c|}
\hline State $^{a}$ & Name of facility & Location $^{\mathrm{a}}$ \\
\hline Czech Republic & $\begin{array}{l}\text { LR-O } \\
\text { Research reactor } \\
\text { University training reactor VR-1 }\end{array}$ & $\begin{array}{l}\text { Řež } \\
\text { Řež } \\
\text { Prague }\end{array}$ \\
\hline Democratic Republic of the Congo & Triga-II & Kinshasa \\
\hline Egypt & $\begin{array}{l}\text { ET RR-1 } \\
\text { MPR }\end{array}$ & $\begin{array}{l}\text { Inshas } \\
\text { Inshas }\end{array}$ \\
\hline Finland & FIR 1 & Espoo \\
\hline Georgia & IRT-M & Tbilisi \\
\hline Germany & $\begin{array}{l}\text { AKR } \\
\text { FRJ-2 } \\
\text { FRM } \\
\text { GKSS } \\
\text { BER-II } \\
\text { FRM-II } \\
\text { SUR-100 } \\
\text { SUR-100 } \\
\text { SUR-100 } \\
\text { SUR-100 } \\
\text { SUR-100 } \\
\text { SUR-100 } \\
\text { SUR-100 } \\
\text { Triga }\end{array}$ & $\begin{array}{l}\text { Dresden } \\
\text { Jülich } \\
\text { Garching } \\
\text { Geesthacht } \\
\text { Berlin } \\
\text { Garching } \\
\text { Furtwangen } \\
\text { Kiel } \\
\text { Ulm } \\
\text { Berlin } \\
\text { Aachen } \\
\text { Hannover } \\
\text { Stuttgart } \\
\text { Mainz }\end{array}$ \\
\hline Ghana & GHARR-1 & Legon-Accra \\
\hline Greece & GRR-1 & Attiki \\
\hline Hungary & $\begin{array}{l}\text { Budapest research reactor } \\
\text { Training reactor }\end{array}$ & $\begin{array}{l}\text { Budapest } \\
\text { Budapest }\end{array}$ \\
\hline Indonesia & $\begin{array}{l}\text { Centre for Research and Development } \\
\text { of Nuclear Techniques } \\
\text { Multipurpose reactor } \\
\text { Yogyakarta Nuclear Research Centre }\end{array}$ & $\begin{array}{l}\text { Bandung } \\
\text { Serpong } \\
\text { Yogyakarta }\end{array}$ \\
\hline Iran, Islamic Republic of & $\begin{array}{l}\text { Esfahan miniature neutron source } \\
\text { reactor } \\
\text { Heavy water zero power reactor } \\
\text { Light water subcritical reactor } \\
\text { TRR }\end{array}$ & $\begin{array}{l}\text { Esfahan } \\
\text { Esfahan } \\
\text { Esfahan } \\
\text { Tehran }\end{array}$ \\
\hline Israel & IRR-1 & Soreq \\
\hline Italy & $\begin{array}{l}\text { AGN-201 } \\
\text { RTS-1 } \\
\text { Tapiro } \\
\text { Triga-II } \\
\text { Triga-RC1 }\end{array}$ & $\begin{array}{l}\text { Palermo } \\
\text { San Piero a Grado } \\
\text { Santa Maria di Galeria } \\
\text { Pavia } \\
\text { Santa Maria di Galeria }\end{array}$ \\
\hline Jamaica & Centre for Nuclear Sciences & Kingston \\
\hline
\end{tabular}




\begin{tabular}{|c|c|c|}
\hline State $^{a}$ & Name of facility & Location $^{\mathrm{a}}$ \\
\hline Japan & $\begin{array}{l}\text { DCA } \\
\text { FCA } \\
\text { HTTR } \\
\text { HTR } \\
\text { JMTR } \\
\text { JMTRCF } \\
\text { JRR-2 } \\
\text { JRR-3 } \\
\text { JRR-4 } \\
\text { Kinki University reactor } \\
\text { KUCA } \\
\text { KUR } \\
\text { Musashi reactor } \\
\text { NSRR } \\
\text { Rikkyo University research reactor } \\
\text { TTCA } \\
\text { Tokyo University-Yayoi } \\
\text { TNCA } \\
\text { TTR } \\
\text { VHTRCA }\end{array}$ & $\begin{array}{l}\text { Oarai-machi, Ibaraki-ken } \\
\text { Tokai-mura, Ibaraki-ken } \\
\text { Higashi-gun, Ibaraki-ken } \\
\text { Kawasaki-shi, Kanagawa-ken } \\
\text { Higashi-gun, Ibaraki-ken } \\
\text { Higashi-gun, Ibaraki-ken } \\
\text { Tokai-mura, Ibaraki-ken } \\
\text { Tokai-mura, Ibaraki-ken } \\
\text { Tokai-mura, Ibaraki-ken } \\
\text { Higashiosaka-shi, Osaka-fu } \\
\text { Osaka } \\
\text { Sennan-gun, Osaka } \\
\text { Kawasaki-shi, Kanagawa-ken } \\
\text { Tokai-mura, Ibaraki-ken } \\
\text { Nagasaka, Kanagawa-ken } \\
\text { Tokai-mura, Ibaraki-ken } \\
\text { Tokai-mura, Ibaraki-ken } \\
\text { Kawasaki-shi } \\
\text { Kawasaki-shi, Kanagawa-ken } \\
\text { Tokai-mura, Ibaraki-ken }\end{array}$ \\
\hline Kazakhstan & $\begin{array}{l}\text { Kurchatov test reactor } \\
\text { WWR-K }\end{array}$ & $\begin{array}{l}\text { Kurchatov } \\
\text { Almaty }\end{array}$ \\
\hline Korea, Republic of & $\begin{array}{l}\text { HANARO } \\
\text { Triga-II and III } \\
\text { AGN-201 }\end{array}$ & $\begin{array}{l}\text { Taejon } \\
\text { Seoul } \\
\text { Suwoon }\end{array}$ \\
\hline Latvia & IRT & Salapils \\
\hline Libyan Arab Jamahiriya & IRT & Tajura \\
\hline Malaysia & Puspati & Bangi, Selangor \\
\hline Mexico & Triga-III & Ocoyoacac \\
\hline Morocco & MA-R1 & Rabat \\
\hline Netherlands & $\begin{array}{l}\text { HFR } \\
\text { HOR } \\
\text { LFR }\end{array}$ & $\begin{array}{l}\text { Petten } \\
\text { Delft } \\
\text { Petten }\end{array}$ \\
\hline Nigeria & Nigeria research reactor 1 & Zaria \\
\hline Norway & $\begin{array}{l}\text { HBWR } \\
\text { Jeep-II }\end{array}$ & $\begin{array}{l}\text { Halden } \\
\text { Kjeller }\end{array}$ \\
\hline Pakistan & $\begin{array}{l}\text { PARR-1 } \\
\text { PARR-2 }\end{array}$ & $\begin{array}{l}\text { Rawalpindi } \\
\text { Rawalpindi }\end{array}$ \\
\hline Peru & $\begin{array}{l}\text { RP-10 } \\
\text { RP-0 }\end{array}$ & $\begin{array}{l}\text { Lima } \\
\text { Lima }\end{array}$ \\
\hline Philippines & PRR & Quezon City, Diliman \\
\hline Poland & Maria & Otwock-Swierk \\
\hline
\end{tabular}




\begin{tabular}{|c|c|c|}
\hline State $^{\mathrm{a}}$ & Name of facility & Location $^{\mathrm{a}}$ \\
\hline Portugal & RPI & Sacavem \\
\hline Romania & $\begin{array}{l}\text { Material testing facility } \\
\text { National Institute R\&D for Physics and } \\
\text { Nuclear Engineering 'Horia Hulubei' }\end{array}$ & $\begin{array}{l}\text { Pitesti Colibasi } \\
\text { Magurele }\end{array}$ \\
\hline Serbia & Vinča Institute of Nuclear Sciences & Vinča \\
\hline Slovenia & Triga-II & Ljubljana \\
\hline South Africa & SAFARI-I & Pelindaba \\
\hline Sweden & Studsvik & Studsvik \\
\hline Switzerland & $\begin{array}{l}\text { AGN 211P } \\
\text { Crocus } \\
\text { Proteus }\end{array}$ & $\begin{array}{l}\text { Basel } \\
\text { Lausanne } \\
\text { Würenlingen }\end{array}$ \\
\hline Syrian Arab Republic & MNSR & Damascus \\
\hline Thailand & TRR & Bangkok \\
\hline Turkey & $\begin{array}{l}\text { Çekmece Nuclear Research and } \\
\text { Training Centre }\end{array}$ & Istanbul \\
\hline Turkey & ITU-TRR Triga-II & Istanbul \\
\hline Ukraine & $\begin{array}{l}\text { IR-100 } \\
\text { WWR-M }\end{array}$ & $\begin{array}{l}\text { Sevastopol } \\
\text { Kiev }\end{array}$ \\
\hline Uzbekistan & $\begin{array}{l}\text { IIN-3M } \\
\text { WWR-SM }\end{array}$ & $\begin{array}{l}\text { Tashkent } \\
\text { Ulugbek }\end{array}$ \\
\hline Venezuela & IVIC & Altos de Pipe \\
\hline Vietnam & $\mathrm{Da}$ Lat research reactor & Da Lat, Lam Dong \\
\hline
\end{tabular}

\section{Conversion plants}

$\begin{array}{lll}\text { Algeria } & \begin{array}{l}\text { Pilot uranium concentration } \\ \text { purification unit }\end{array} & \text { Draria nuclear site } \\ \text { Argentina } & \begin{array}{l}\mathrm{UF}_{6} \text { production plant } \\ \mathrm{UO}_{2} \text { conversion plant } \\ \text { Canada }\end{array} & \begin{array}{l}\text { Pameco Corporation Blind River } \\ \text { Córdoba }\end{array} \\ & \begin{array}{l}\text { refinery } \\ \text { Cameco Corporation Port Hope } \\ \text { conversion facility }\end{array} & \text { Blind River } \\ & \begin{array}{l}\text { Experimental conversion laboratory } \\ \text { Chile }\end{array} & \text { Santiago } \\ \text { Iran, Islamic Republic of } & \begin{array}{l}\text { Uranium chemistry laboratory } \\ \text { UCF }\end{array} & \begin{array}{l}\text { Esfahan } \\ \text { Esfahan }\end{array}\end{array}$




\begin{tabular}{|c|c|c|}
\hline State $^{\mathrm{a}}$ & Name of facility & Locatio \\
\hline Japan & $\begin{array}{l}\text { JCO } \\
\text { JNC } \\
\text { Plutonium conversion development } \\
\text { facility }\end{array}$ & $\begin{array}{l}\text { Tokai-mura, Ibarak } \\
\text { Tomata-gun, Okaya } \\
\text { Tokai-mura, Ibarak }\end{array}$ \\
\hline Korea, Republic of & DUF4 conversion plant & Taejon \\
\hline Mexico & Fuel fabrication pilot plant & Salazar \\
\hline Romania & $\begin{array}{l}\text { Sinterable } \mathrm{UO}_{2} \text { powder processing } \\
\text { plant }\end{array}$ & Feldiora \\
\hline South Africa & $\begin{array}{l}\text { Conversion plant } \\
\text { HEU and LEU conversion, alloy } \\
\text { production, scrap recovery plant }\end{array}$ & $\begin{array}{l}\text { Pelindaba } \\
\text { Pelindaba }\end{array}$ \\
\hline Sweden & Ranstad Mineral & Stenstorp \\
\hline Fabrication plants & & \\
\hline Algeria & UDEC & Draria nuclear site \\
\hline Argentina & $\begin{array}{l}\text { Experimental plant } \\
\text { Fuel fabrication plant } \\
\text { Research reactors fuel elements } \\
\text { fabrication plant } \\
\text { Research reactor fuel fabrication plant }\end{array}$ & $\begin{array}{l}\text { Constituyentes } \\
\text { Ezeiza } \\
\text { Constituyentes } \\
\text { Ezeiza }\end{array}$ \\
\hline Belgium & $\begin{array}{l}\text { BN-MOX } \\
\text { FBFC } \\
\text { FBFC MOX }\end{array}$ & $\begin{array}{l}\text { Dessel } \\
\text { Dessel } \\
\text { Dessel }\end{array}$ \\
\hline Brazil & Fuel fabrication plant & Resende \\
\hline Canada & $\begin{array}{l}\text { Fuel engineering, metallurgy, } \\
\text { workshops, metallurgy and chemical } \\
\text { operations } \\
\text { Fuel fabrication facility } \\
\text { General Electric Canada } \\
\text { General Electric Canada } \\
\text { Zircatec Precision Industries }\end{array}$ & $\begin{array}{l}\text { Chalk River } \\
\text { Toronto } \\
\text { Peterborough } \\
\text { Port Hope }\end{array}$ \\
\hline Chile & UMF & Santiago \\
\hline Egypt & $\begin{array}{l}\text { FMPP } \\
\text { Research and development nuclear fuel } \\
\text { laboratory }\end{array}$ & $\begin{array}{l}\text { Inshas } \\
\text { Inshas }\end{array}$ \\
\hline Germany & Advanced Nuclear Fuels & Lingen \\
\hline India & $\begin{array}{l}\text { CFFAA } \\
\text { NFC }\end{array}$ & $\begin{array}{l}\text { Hyderabad } \\
\text { Hyderabad }\end{array}$ \\
\hline Indonesia & $\begin{array}{l}\text { Experimental fuel element installation } \\
\text { Research reactor fuel element } \\
\text { production installation }\end{array}$ & $\begin{array}{l}\text { Serpong } \\
\text { Serpong }\end{array}$ \\
\hline
\end{tabular}




\begin{tabular}{|c|c|c|}
\hline State $^{\mathrm{a}}$ & Name of facility & Location $^{\mathrm{a}}$ \\
\hline Iran, Islamic Republic of & Fuel fabrication laboratory & Esfahan \\
\hline Italy & $\begin{array}{l}\text { FN-Nuovo Technologie e Servizi } \\
\text { Avanzati }\end{array}$ & Bosco Marengo \\
\hline Japan & $\begin{array}{l}\text { Global Nuclear Fuel } \\
\text { Mitsubishi Nuclear Fuel } \\
\text { NFI Kumatori-1 } \\
\text { Tokai-1 } \\
\text { NFI Kumatori-2 } \\
\text { Plutonium fuel production facility } \\
\text { PFC plutonium fuel facility }\end{array}$ & $\begin{array}{l}\text { Yokosuka-shi, Kanagawa-ken } \\
\text { Tokai-mura, Ibaraki-ken } \\
\text { Sennan-gun, Osaka } \\
\text { Tokai-mura, Ibaraki-ken } \\
\text { Sennan-gun, Osaka } \\
\text { Tokai-mura, Ibaraki-ken } \\
\text { Tokai-mura, Ibaraki-ken }\end{array}$ \\
\hline Kazakhstan & Ulbinski metallurgical plant & Kamenogorsk \\
\hline Korea, Republic of & Korea nuclear fuel fabrication plant & Taejon \\
\hline Romania & NFP & Pitesti Colibasi \\
\hline South Africa & BEVA & Pelindaba \\
\hline Spain & ENUSA fuel fabrication plant & Juzbado \\
\hline Sweden & $\mathrm{ABB}$ & Västeras \\
\hline Turkey & Nuclear fuel pilot plant & Istanbul \\
\hline
\end{tabular}

Reprocessing plants

$\begin{array}{lll}\text { Germany } & \text { WAK } & \text { Eggenstein-Leopoldshafen } \\ \text { India } & \text { PREFRE } & \text { Tarapur } \\ \text { Italy } & \text { Eurex } & \text { Saluggia } \\ & \text { ITREC } & \text { Rotondella } \\ & \text { Chemical processing facility (JAEA } & \text { Tokai-mura, Ibaraki-ken } \\ \text { Japan } & \text { Tokai research and development) } & \\ & \text { Rokkasho reprocessing plant } & \text { Kamikita-gun, Aomori-ken } \\ & \text { Solution critical facility of NUCEF } & \text { Tokai-mura, Ibaraki-ken } \\ & \text { Tokai reprocessing plant } & \text { Tokai-mura, Ibaraki-ken }\end{array}$

\section{Enrichment plants}

$\begin{array}{lll}\begin{array}{ll}\text { Argentina } \\ \text { Brazil }\end{array} & \begin{array}{l}\text { Uranium enrichment plant } \\ \text { Isotopic enrichment laboratory } \\ \text { Laser spectroscopy laboratory } \\ \text { U-235 centrifuge enrichment plant } \\ \text { Uranium enrichment pilot plant }\end{array} & \begin{array}{l}\text { Pilcaniyeu } \\ \text { Ipão José dos Campos } \\ \text { Resende } \\ \text { Iperó }\end{array} \\ \text { China } & \text { Shaanxi uranium enrichment plant } & \text { Han Zhang } \\ \text { Germany } & \text { UTA-1 } & \text { Gronau } \\ \text { Iran, Islamic Republic of } & \text { Fuel enrichment plant } & \text { Natanz } \\ & \text { Pilot fuel enrichment plant } & \text { Natanz }\end{array}$




\begin{tabular}{lll}
\hline State $^{\mathrm{a}}$ & \multicolumn{1}{c}{ Name of facility } & \multicolumn{1}{c}{ Location $^{\mathrm{a}}$} \\
\hline Japan & $\begin{array}{l}\text { Rokkasho enrichment and disposal } \\
\text { office centrifuge test facility } \\
\text { Rokkasho uranium enrichment plant } \\
\text { Uranium enrichment plant }\end{array}$ & $\begin{array}{l}\text { Kitakami-gun, Aomori-ken } \\
\text { Kamikita-gun, Aamori-ken } \\
\text { Tomata-gun, Okayama-ken }\end{array}$ \\
Netherlands & URENCO SP4, SP5 & Almelo \\
United Kingdom & URENCO A3, E22 and E23 & Capenhurst
\end{tabular}

\section{Separate storage facilities}

\begin{tabular}{|c|c|c|}
\hline Argentina & $\begin{array}{l}\text { Central store } \\
\text { Central store } \\
\text { DUE } \\
\text { Nuclear material storage } \\
\text { Storage bunker }\end{array}$ & $\begin{array}{l}\text { Ezeiza } \\
\text { Constituyentes } \\
\text { Ezeiza } \\
\text { Constituyentes } \\
\text { Ezeiza }\end{array}$ \\
\hline Armenia & Dry spent fuel storage & Metsamor \\
\hline Australia & Vault storage & Lucas Heights \\
\hline Belgium & $\begin{array}{l}\text { Belgoprocess dry storage } \\
\text { Belgoprocess } \\
\text { Electrabel Doel Droge Stockage } \\
\text { Zone de production nucléaire de } \\
\text { Tihange }\end{array}$ & $\begin{array}{l}\text { Dessel } \\
\text { Dessel } \\
\text { Beveren } \\
\text { Tihange }\end{array}$ \\
\hline Brazil & $\begin{array}{l}\text { Aramar store } \\
\mathrm{UF}_{6} \text { production }\end{array}$ & $\begin{array}{l}\text { Iperó } \\
\text { São Paulo }\end{array}$ \\
\hline Bulgaria & AFRS & Kozloduy \\
\hline Canada & $\begin{array}{l}\text { AECL Research } \\
\text { CRL spent fuel storage facility } \\
\text { Douglas Point dry irradiated fuel } \\
\text { storage } \\
\text { Gentilly-I dry irradiated fuel storage } \\
\text { facility } \\
\text { Nuclear material storage facility } \\
\text { Pickering used fuel dry storage facility } \\
\text { Spent fuel dry canister storage facility } \\
\text { Spent fuel storage facility } \\
\text { Western used fuel dry storage facility }\end{array}$ & $\begin{array}{l}\text { Pinawa } \\
\text { Chalk River } \\
\text { Tiverton } \\
\text { Gentilly } \\
\text { Chalk River } \\
\text { Pickering } \\
\text { Chalk River } \\
\text { Chalk River } \\
\text { Tiverton }\end{array}$ \\
\hline Czech Republic & $\begin{array}{l}\text { High level radioactive waste storage } \\
\text { Dukovany interim spent fuel storage } \\
\text { Skoda Plzen-Bolevec storage }\end{array}$ & $\begin{array}{l}\text { Řež } \\
\text { Dukovany } \\
\text { Bolevec }\end{array}$ \\
\hline Denmark & $\begin{array}{l}\text { Risø store } \\
\text { Danish decommissioning waste } \\
\text { treatment plant }\end{array}$ & $\begin{array}{l}\text { Roskilde } \\
\text { Roskilde }\end{array}$ \\
\hline Finland & TVO-KPA store & Olkiluoto \\
\hline France & COGEMA UP2 and UP3 & La Hague \\
\hline
\end{tabular}




\begin{tabular}{|c|c|c|}
\hline State $^{\mathrm{a}}$ & Name of facility & Location $^{\mathrm{a}}$ \\
\hline \multirow[t]{28}{*}{ Germany } & $\begin{array}{l}\text { AVR-Behaelterlager für Bestrahlte } \\
\text { Brennelementkugeln }\end{array}$ & Jülich \\
\hline & Brennelementbehaelterlager & Grafenrheinfeld \\
\hline & Grafenrheinfeld & \\
\hline & Brennelemente-Zwischenlager Biblis & Biblis \\
\hline & Brennelemente-Zwischenlager & Gundremmingen \\
\hline & Gundremmingen & \\
\hline & Brennelementlager Isar & Essenbach \\
\hline & Brennelement-Zwischenlager Ahaus & Ahaus \\
\hline & $\begin{array}{l}\text { Gemeinschaftskernkraftwerk Neckar, } \\
\text { Zwischenlager }\end{array}$ & Neckarwestheim \\
\hline & Kernmateriallager Gebaeude 87 & Rossendorf \\
\hline & Lager der Kernforschungsanlage Jülich & Jülich \\
\hline & für Bestr Ahlte Avr & \\
\hline & Brennelement-Kugeln & \\
\hline & NCS, Lagerhalle Hanau, Geb. 15 & Hanau \\
\hline & Staatliches Spaltstofflager für & Hanau \\
\hline & Plutonium und hochangereichertes & \\
\hline & Uran & \\
\hline & Standort Zwischenlager Kruemmel & Geesthacht \\
\hline & Standort Zwischenlager Philippsburg & Philipsburg \\
\hline & Standort-Zwischenlager Lingen & Lingen \\
\hline & Standortzwischenlager Brunsbuettel & Brunsbuettel \\
\hline & Transportbehaelterlager Gorleben & Gorleben \\
\hline & Zwischenlager Kernkraftwerk Grohnde & Emmerthal \\
\hline & Zwischenlager Nord & Lubmin \\
\hline & Zwischenlager-Kernkraftwerk & Brokdorf \\
\hline & Brokdorf & \\
\hline & Zwischenlager-Kernkraftwerk & Stadland \\
\hline & Unterweser & \\
\hline \multirow[t]{2}{*}{ Hungary } & Central isotope storage & Budapest \\
\hline & MVDS & Paks \\
\hline India & AFR & Tarapur \\
\hline Indonesia & $\begin{array}{l}\text { Transfer channel and interim storage } \\
\text { for spent fuel }\end{array}$ & Serpong \\
\hline Iran, Islamic Republic of & Karaj radioactive waste storage & Karaj \\
\hline Iraq & Tuwaitha, location $\mathrm{C}$ & Tuwaitha \\
\hline \multirow[t]{5}{*}{ Italy } & Deposito Avogadro & Turin \\
\hline & INE, non-irradiated nuclear material & Ispra \\
\hline & Essor storage pond & Ispra \\
\hline & Nucleco & Rome \\
\hline & Research centre & Ispra \\
\hline \multirow[t]{2}{*}{ Japan } & $\begin{array}{l}\text { Fukushima Dai-ichi common spent } \\
\text { fuel storage facility }\end{array}$ & Futaba-gun, Fukushima-ken \\
\hline & Kyoto University fresh fuel storage & Sennan-gun, Osaka \\
\hline Kazakhstan & Ulba thorium storage & Kamenogorsk \\
\hline Korea, Republic of & Nuclear material storage facility & Taejon \\
\hline
\end{tabular}




\begin{tabular}{|c|c|c|}
\hline State $^{\mathrm{a}}$ & Name of facility & Location $^{\mathrm{a}}$ \\
\hline Lithuania & Ignalina spent fuel dry storage & Visaginas \\
\hline Netherlands & $\begin{array}{l}\text { COVRA } \\
\text { COVRA - Habog }\end{array}$ & $\begin{array}{l}\text { Vlissingen } \\
\text { Vlissingen }\end{array}$ \\
\hline Pakistan & Hawks Bay depot & Karachi \\
\hline Poland & Radioactive waste management plant & Swierk \\
\hline Portugal & Instalacao de Armazenagem & Sacavem \\
\hline Romania & Interim dry spent fuel storage & Cernavoda \\
\hline Slovakia & Bohunice interim store & Bohunice \\
\hline Slovenia & CSRAO, ARAO & Brinje \\
\hline South Africa & $\begin{array}{l}\text { Bulk storage facility } \\
\text { Decommissioned pilot enrichment } \\
\text { plant } \\
\text { E building storage facility } \\
\text { HEU storage vault } \\
\text { Koeberg Castor storage facility } \\
\text { Thabana pipe store } \\
\text { Waste storage facility } \\
\text { Z plant storage facility }\end{array}$ & $\begin{array}{l}\text { Pelindaba } \\
\text { Pelindaba } \\
\text { Valindaba } \\
\text { Pelindaba } \\
\text { Cape Town } \\
\text { Pelindaba } \\
\text { Pelindaba } \\
\text { Pelindaba }\end{array}$ \\
\hline Spain & Intermediate dry spent fuel storage & Trillo \\
\hline Sweden & SKB clab store & Oskarshamn \\
\hline Switzerland & $\begin{array}{l}\text { Central interim storage facility } \\
\text { SAPHIR }\end{array}$ & $\begin{array}{l}\text { Würenlingen } \\
\text { Würenlingen }\end{array}$ \\
\hline USA & $\begin{array}{l}\mathrm{K} \text { area materials storage facility } \\
\text { Plutonium storage } \\
\text { Tube vault } 16\end{array}$ & $\begin{array}{l}\text { Savannah River Site } \\
\text { Hanford } \\
\text { Oak Ridge }\end{array}$ \\
\hline Ukraine & $\begin{array}{l}\text { Spent fuel storage } \\
\text { Fresh fuel storage Khmelnitski } \\
\text { Fresh fuel storage } \\
\text { Fresh fuel storage } \\
\text { Dry spent nuclear fuel storage facility } \\
\text { Fresh fuel storage }\end{array}$ & $\begin{array}{l}\text { Chernobyl } \\
\text { Neteshin } \\
\text { Kuznetsovsk } \\
\text { Yuzhnoukrainsk } \\
\text { Energodar } \\
\text { Energodar }\end{array}$ \\
\hline United Kingdom & $\begin{array}{l}\text { Special nuclear material store } 9 \\
\text { Thorp product store }\end{array}$ & $\begin{array}{l}\text { Sellafield } \\
\text { Sellafield }\end{array}$ \\
\hline
\end{tabular}

\section{Other facilities}

Algeria

Argentina
AURES I

Alpha laboratory

Enriched uranium recovery laboratory

Fission products division

Radiochemical facility laboratory

Post-irradiation testing laboratory
Ain Oussara

Constituyentes

Ezeiza

Ezeiza

Ezeiza

Ezeiza 


\begin{tabular}{|c|c|c|}
\hline State $^{\mathrm{a}}$ & Name of facility & Location $^{\mathrm{a}}$ \\
\hline & LTA & Ezeiza \\
\hline & Uranium powder fabrication plant & Constituyentes \\
\hline Australia & Research and development laboratories & Lucas Heights \\
\hline \multirow[t]{5}{*}{ Belgium } & CEN waste & Dessel \\
\hline & IRMM & Geel \\
\hline & IRE & Fleurus \\
\hline & Laboratoires plutonium du CEN/SCK & Mol \\
\hline & SCK-CEN laboratories & Mol \\
\hline \multirow[t]{5}{*}{ Brazil } & $\begin{array}{l}\text { Fuel development and technology } \\
\text { coordination }\end{array}$ & São Paulo \\
\hline & $\begin{array}{l}\text { Isotope separation element } \\
\text { development laboratory }\end{array}$ & São Paulo \\
\hline & $\begin{array}{l}\text { Nuclear fuel and instrumentation } \\
\text { development laboratory }\end{array}$ & São Paulo \\
\hline & Nuclear materials laboratory & Iperó \\
\hline & Reprocessing project & São Paulo \\
\hline \multirow[t]{3}{*}{ Czech Republic } & Nuclear fuel institute & Prague \\
\hline & Radioactive waste repository & Litomerice \\
\hline & Research laboratories & Řež \\
\hline \multirow[t]{2}{*}{ Georgia } & Subcritical assembly & Tbilisi \\
\hline & Sukhumi Institute & Sukhumi \\
\hline \multirow[t]{6}{*}{ Germany } & Deutsches Elektronen-Synchrotron & Hamburg \\
\hline & Heisse Zellen der & Jülich \\
\hline & Kernforschungsanlage & \\
\hline & Laboratorien der & Jülich \\
\hline & Kernforschungsanlage & \\
\hline & Transuran Institut & Leopoldshafen \\
\hline Indonesia & Radiometallurgy installation & Serpong \\
\hline Iran, Islamic Republic of & $\begin{array}{l}\text { Jabr Ibn Hayan multipurpose } \\
\text { laboratory }\end{array}$ & Tehran \\
\hline Italy & Laboratorio plutonio & Santa Maria di Galeria \\
\hline \multirow[t]{13}{*}{ Japan } & JAERI Oarai research establishment & Higashi, Ibaraki-ken \\
\hline & JAERI Tokai research establishment & Tokai-mura, Ibaraki-ken \\
\hline & JNC fuel monitoring facility & Higashi, Ibaraki-ken \\
\hline & JNC irradiation rig assembling facility & Higashi-gun, Ibaraki-ken \\
\hline & $\begin{array}{l}\text { JNC Oarai research and development } \\
\text { facility }\end{array}$ & Higashi, Ibaraki-ken \\
\hline & JNC Tokai research and development & Tokai-mura, Ibaraki-ken \\
\hline & Kyoto University, Kumatori & Sennan-gun, Osaka \\
\hline & Neutron radiation facility & Tsukuba-shi, Ibaraki-ken \\
\hline & NDC fuel hot laboratory & Tokai-mura, Ibaraki-ken \\
\hline & NERL, University of Tokyo & Tokai-mura, Ibaraki-ken \\
\hline & NFI Tokai-2 & Tokai-mura, Ibaraki-ken \\
\hline & NFD research facility & Higashi, Ibaraki-ken \\
\hline & Uranium material laboratory & Higashi, Ibaraki-ken \\
\hline
\end{tabular}




\begin{tabular}{|c|c|c|}
\hline State $^{a}$ & Name of facility & Location $^{\mathrm{a}}$ \\
\hline Korea, Republic of & $\begin{array}{l}\text { Advanced spent fuel conditioning } \\
\text { process demonstration facility } \\
\text { DUPIC fuel development facility } \\
\text { HANARO fuel fabrication laboratory } \\
\text { Irradiation material examination } \\
\text { facility } \\
\text { Nuclear fuel cycle related R\&D facility } \\
\text { Post-irradiation examination facility } \\
\text { Acrylonitrile plant }\end{array}$ & $\begin{array}{l}\text { Taejon } \\
\text { Taejon } \\
\text { Taejon } \\
\text { Taejon } \\
\text { Taejon } \\
\text { Taejon } \\
\text { Ulsan }\end{array}$ \\
\hline Libyan Arab Jamahiriya & Tajura uranium R\&D facility & Tajura \\
\hline Netherlands & ECN and JRC & Petten \\
\hline Norway & Research laboratories & Kjeller \\
\hline South Africa & $\begin{array}{l}\text { Hot cell complex } \\
\text { Decontamination and waste recovery } \\
\text { plant } \\
\text { NU and DU metals plant }\end{array}$ & $\begin{array}{l}\text { Pelindaba } \\
\text { Pelindaba } \\
\text { Pelindaba }\end{array}$ \\
\hline Spain & ENRESA & El Cabril \\
\hline Switzerland & $\begin{array}{l}\text { CERN } \\
\text { EIR }\end{array}$ & $\begin{array}{l}\text { Geneva } \\
\text { Würenlingen }\end{array}$ \\
\hline Ukraine & $\begin{array}{l}\text { Chernobyl unit } 4 \text { shelter } \\
\text { National Science Center-Kharkov } \\
\text { Institute of Physics and Technology } \\
\text { Subcritical uranium water assembly }\end{array}$ & $\begin{array}{l}\text { Chernobyl } \\
\text { Kharkov } \\
\text { Sevastopol }\end{array}$ \\
\hline United States of America & BWX Technologies facility & Lynchburg \\
\hline
\end{tabular}

${ }^{\text {a }}$ An entry in this column does not imply the expression of any opinion whatsoever on the part of the Agency concerning the legal status of any country or territory or of its authorities, or concerning the delimitation of its frontiers.

Note: The Agency was also applying safeguards in Taiwan, China, at eight power reactors, three research reactors/critical assemblies, one uranium pilot conversion plant, one fuel fabrication plant, one storage facility and one R\&D facility.

Note: Additionally under Agency safeguards there were more than 300 locations outside facilities in 45 States. 